Article

\title{
The Influence of Calcareous Fly Ash on the Effectiveness of Plasticizers and Superplasticizers
}

\author{
Jacek Gołaszewski ${ }^{D}$, Tomasz Ponikiewski *(D, Aleksandra Kostrzanowska-Siedlarz ${ }^{(D)}$ and \\ Patrycja Miera
}

Department of Building Processes and Building Physics, Faculty of Civil Engineering, Silesian University of Technology, 44-240 Gliwice, Poland; Jacek.Golaszewski@polsl.pl (J.G.);

Aleksandra.Kostrzanowska-Siedlarz@polsl.pl (A.K.-S.); Patrycja.Miera@polsl.pl (P.M.)

* Correspondence: Tomasz.Ponikiewski@polsl.pl

Received: 9 April 2020; Accepted: 11 May 2020; Published: 13 May 2020

check for updates

\begin{abstract}
Due to the rational shaping of the environment and the management of environmental resources in accordance with the principle of sustainable development, calcareous fly ash (CFA) - high-calcium as a by-product of lignite combustion-is a valuable addition to concrete. This additive, however, due to its high-water demand lowers the workability of the concrete mix, which is a problem, especially in the first $90 \mathrm{~min}$ after mixing the components of the mix. In order to meet this challenge, plasticizers $(\mathrm{P})$ and superplasticizers $(\mathrm{SP})$ for concrete are used with various effects which are designed to reduce the yield value and plastic viscosity. To check the technical efficiency of admixtures $\mathrm{P}$ and SP with different chemical bases, the main objective of this research was to investigate the influence of raw and ground CFA on the rheological properties and other side effects of admixtures, such as the amount of air in the mixture and the amount of heat of hydration. The use of P, particularly SP, effectively improves the workability of the mortar containing CFA, especially ground CFA. With these admixtures, it is possible to obtain mortars containing ground CFA with similar rheological properties to mortars without its addition. To obtain a specific workability of mortar with CFA, it is usually necessary to introduce a higher dose of P or SP than used for mortars without CFA. The presence of raw CFA does not alter the effectiveness of $P$ and strongly reduces the effectiveness of SP. The reduced effectiveness of SP manifests primarily as a high workability lost. The presence of ground CFA does not change the effectiveness of $\mathrm{P}$ (or is higher). The effectiveness of the superplasticizer SNF (with a chemical base of naphthalene sulfonate) and PE (with a chemical base of polycarboxylate ether) is slightly lower or does not change. The effectiveness of the superplasticizer SMF (with a chemical base of melamine sulfonates) is significantly lower. We found that the presence of ash affects the efficiency of $\mathrm{P}$ and SP, while processing via the grinding of ash makes the effect negligible. These results are novel in both their cognitive and practical aspects.
\end{abstract}

Keywords: calcareous fly ash; plasticizer; superplasticizer; rheological properties; fly ash processing methods; cement mortars, workability

\section{Introduction}

Waste management for the coal fired power plants is gaining key importance in connection with threats to the environment and health. Such power plants in Poland alone produce millions of tons of fly ash per year, whose properties depend on the type of coal (lignite or hard coal) and the method of combustion. The reuse of this fly ash in the composition of concrete relates to sustainable development by reducing the amount of cement and thereby reducing cement production, which is associated with a reduction in the amount of $\mathrm{CO}_{2}$ released into the atmosphere. In addition to this ecological aspect, there is also an economic one, as fly ash can provide measurable benefits to investors by replacing 
cement and clinker with waste materials. Fly ash from the combustion of hard coal is characterized by its pozzolanic properties, and due to its beneficial effect on the properties of concrete, it is a valued and widely used addition to concrete. When lignite is burned, calcareous fly-ash (CFA) is produced-i.e., fly ash that contains large amounts of calcium compounds. However, due to its composition and physical properties, not every CFA is suitable for concrete [1]. The studies carried out to date [2] show that, among the CFA available in Poland, only the CFA from the Bełchatów power plant has properties that allow it to be used as an additive to cement and concrete. This CFA has high pozzolanic and hydraulic activity and meets the requirements of the EN 197-1 standard [3] for the main constituents of common cement. After the grinding process, it can also be used as an active mineral additive to concrete [1,3-5]. As established in several studies [6-12], the use of this CFA in up to $30 \%$ of cement as an additive to concrete or as the main component of cement, in general, does not negatively influence the strength and durability of the concrete. Notably, it is necessary to use CFA processed by grinding, not in a raw state. Moreover, the authors in [13] investigated the effects of nanoclay additions on the fresh properties, mechanical performance, and microstructure properties of high volume fly ash mixes designed for 3D printing. The results in [13] showed that the addition of high volume fly ash improved the thixotropic properties of the mixtures, thus increasing its suitability for concrete printing applications.

Unfortunately, the use of CFA as a concrete additive is significantly hindered by problems related to fresh concrete's workability. In a raw state, CFA is characterized by very high water demands, much higher than those of cement $[5,14]$. These demands can be reduced by processing, preferably by grinding [2,14]. Even then, the water demands remain higher than those of cement $[2,6]$. The high water demands of CFA make it difficult to obtain fresh concrete with the required stable workability in the long term, whether it is used as an additive to cement or as an additive to concrete [6,12-18]. The processing of CFA solves this problem to some extent, but it should be noted that the use of ground CFA undoubtedly has a beneficial effect on the rheological properties of mortars and their variability $[12,14,16-18]$.

Therefore, to obtain the required workability of CFA containing concrete, it is necessary to use plasticizers (P) or superplasticizers (SP). Indeed, the possibility of using CFA is conditional on the use of these admixtures [12,14,18]. Therefore, the effectiveness of these admixtures in the presence of CFA is particularly important. However, the experimental data on this topic has been limited. In general, to obtain a specific workability of fresh concrete with CFA, it is necessary to use more P or SP than for of the corresponding compositions without CFA [16-22]. This is likely due primarily to the higher water demand of fresh concrete with CFA. Consequently, there is a smaller amount of free water in the mixture [23]. The potentially lower efficiency of P and SP in the presence of CFA is indicated by the faster loss of workability of mixes with CFA [6], but such effects do not occur in every case $[16,17,22]$. To date, there has been no in-depth study on how different types of $\mathrm{P}$ and SP work with CFA with different properties, both in terms of the primary effect-the rheological properties of the mortars—and the secondary effects—setting time, air entrainment, or hydration heat. Generally, this indicates that present knowledge of the impact of CFA on the effectiveness of P and SP is very limited and not systematic; thus, further studies are needed.

The main objective of this research was to investigate the influence of raw and ground CFA on the effectiveness of $\mathrm{P}$ and SP activity. The basic effect of $\mathrm{P}$ and SP on rheological properties was studied using rheometric techniques. The secondary effects of the admixture's effects, such as setting time, heat of hydration, and air content, were also studied.

\section{Effectiveness of Plasticizers and Superplasticizer Action}

The effectiveness (efficiency) of concrete admixtures is a criterion based on the characteristics of the quality of its effects in its given function and its associated primary effect [24]. The primary effect is defined here as an effect of the admixture corresponding to its function as a direct consequence of the physical mechanism of its action. Typically, the assessment of the effectiveness of an admixture and its applications should take into account secondary effects because of the possible adverse impact of the 
admixture on the important properties of the concrete and (or) the hardened concrete. The types and primary and secondary effects of $\mathrm{P}$ and SP are summarized in Table 1.

Table 1. Types, primary and secondary effects of plasticizers (P) and superplasticizers (SP) [24].

\begin{tabular}{|c|c|c|c|}
\hline Admixture & Type & Primary Effect & $\begin{array}{c}\text { Secondary Effects-Side } \\
\text { Effects }\end{array}$ \\
\hline $\mathrm{P}$ & $\begin{array}{l}\text { - lignosulfonates and its salts }(\mathrm{Ca} \text {, } \\
\mathrm{Na}, \mathrm{Mg}, \mathrm{NH} 4) \text {; } \\
\text { hydroxy-carboxylate acids and } \\
\text { its salts (containing groups }(\mathrm{OH}) \text {, } \\
(\mathrm{COOH})) \text {. }\end{array}$ & \multirow{2}{*}{$\begin{array}{l}\text { Influence on rheological } \\
\text { properties of cement mixtures } \\
\text { enabling: } \\
\text { - } \quad \begin{array}{l}\text { increase in workability } \\
\text { (fluidity) of mixture }\end{array} \\
\text { (constant } \mathrm{w} / \mathrm{b} \text { ratio) } \\
\text { - decrease in } \mathrm{w} / \mathrm{b} \text { ratio at given } \\
\text { workability of cement } \\
\text { mixture (enabling increase in } \\
\text { compressive strength and } \\
\text { durability of hardened } \\
\text { cement composite) } \\
\text { decrease in cement content at } \\
\text { given fresh and hardened } \\
\text { cement mixture properties }\end{array}$} & \multirow{2}{*}{$\begin{array}{l}\text { - } \quad \text { influence on cement } \\
\text { setting time } \\
\text { - } \quad \text { influence on air } \\
\text { content in mixture } \\
\text { - } \quad \text { influence on heat of } \\
\text { cement hydration }\end{array}$} \\
\hline SP & 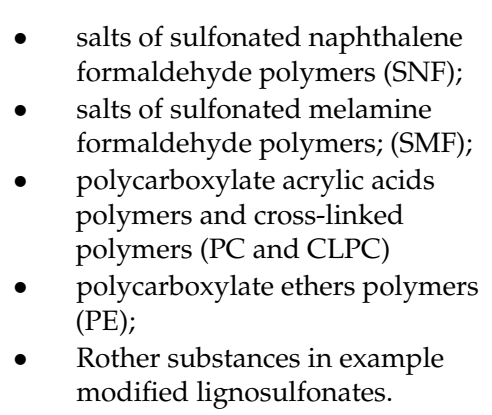 & & \\
\hline
\end{tabular}

The effectiveness of $\mathrm{P}$ and SP should be considered from technical, technological, and economic perspectives. Technical effectiveness determines the changes in the rheological properties of the fresh concrete in terms of the minimum dosage of admixture needed for its effects to take place in the intended time needed for transporting and arranging the mix at the installation site; the conventionally adopted time is $90 \mathrm{~min}$. Economic effectiveness refers to the cost of obtaining certain changes in the rheological properties using the above additives. Technological effectiveness is the ease and safety of using the admixture and the sensitivity of its effects to changes in environmental conditions. This article focuses on the technical and rheological aspects of the effectiveness of P and SP in the presence of CFA. In practice, the choice of admixture also depends on economic and technological factors. The fulfilment of these factors will achieve the desired effect of the admixture at the lowest cost and in a safe manner.

The aim of using P and SP is to adequately modify the rheological properties of the fresh concrete according to the technology used and the conditions for the implementation process of concreting. The basis for evaluating the effectiveness of these additives is measuring their impact on the changes of their rheological properties and workability. Therefore, the effectiveness tests of these admixtures focus primarily on the identification effect on the rheology of fresh concrete under certain technological conditions and the possibility of side effects of the admixtures, such as changes in the aeration of the mix or changes in the heat release curve during cement hydration. For this purpose, it is necessary to adopt a rheological model of the fresh concrete, and then measure the changes in its rheological parameters alongside the air content in the mix and changes in the nature of heat release during the hydration process, as a result of the addition of an admixture in terms of the variable factors and type of the concrete components.

Physically, mortar and concrete are similar. Both are a mixture of cement, water, aggregate, admixtures, and additives. Numerous studies show that the tests carried out on mortars can also be used to predict the rheological properties of fresh concrete. Simple mathematical relationships between the rheological properties of fresh mortars and fresh concrete mixes are presented in past studies [25-33]. Thus, it is commonly accepted that mortars can be used to test the effectiveness of $P$ and SP. Thanks to this, the cost of research can be significantly reduced, and its scope can be increased. 
Therefore, studies on the effects of CFA on the performance of plasticizers and superplasticizers were also performed on mortars.

\section{Experimental Section}

\subsection{Variables and Research Plan}

The research plan is presented in Table 2. The research was conducted for three batches of CFA (raw fly ash; batches: A, B, C, and ground fly ash; batches: AG, BG, and CG), sampled in a time range of a half year from the intermediate reservoirs of the Bełchatów Power Plant. We used both raw and ground CFA, which were added as a substitute for $20 \%$ of the cement mass. The effectiveness of different admixtures was assessed by testing changes in the rheological properties of the mortars and the testing side effects of the admixture, including the heat of hydration and air content, with and without CFA. We selected two P and four SP that are typically used and represent the main types of this admixture. Admixtures were also selected based on their different chemical bases that were representative of the given admixture group: For P: lignosulfonates, iminodietanol, bis ethanol, phosphate (V) tri butyl acetate, formaldehyde, methanol, and (Z)-octadec-9-enyloamine; for SP: polycarboxylate ether, melamine sulfonates, and naphthalene sulfonate.

Table 2. Research plan-type of calcareous fly ash (CFA), w/b ratio, admixture dosage and tested properties.

\begin{tabular}{|c|c|c|c|c|c|c|}
\hline $\begin{array}{c}\text { Type and Batches } \\
\text { of Calcareous Fly } \\
\text { Ash (CFA) }\end{array}$ & $\begin{array}{c}\mathbf{w} / \mathbf{b} \\
\text { Ratio }\end{array}$ & \multicolumn{2}{|c|}{$\begin{array}{l}\text { Symbol of } \\
\text { Admixture }\end{array}$} & $\begin{array}{c}\text { For Testing } \\
\text { Rheological Properties } \\
{[\% \text { b.m }]}\end{array}$ & $\begin{array}{c}\text { For Testing } \\
\text { Air Content } \\
\text { [\% b.m] }\end{array}$ & $\begin{array}{c}\text { For Testing Heat } \\
\text { of Hydration } \\
\text { [\% b.m] }\end{array}$ \\
\hline \multirow{6}{*}{$\begin{array}{c}\text { Raw CFA: } \\
\text { A B, C } \\
\text { Ground CFA: AG, } \\
\text { BG, CG } \\
\text { CFA content: } 20 \% \text { as } \\
\text { cement mass } \\
\text { replacement }\end{array}$} & 0.55 & \multirow{2}{*}{$\mathrm{P}$} & P1 & $0,0.25,0.5 \%$ & $0,0.25 \%$ & $x$ \\
\hline & 0.55 & & P2 & $0,0.25,0.5 \%$ & $0,0.25 \%$ & $0,0.25 \%$ \\
\hline & 0.55 & \multirow{4}{*}{ SP } & SMF & $0,0.6,1.15,2.3 \%$ & $0,1.15 \%$ & $0,1.15 \%$ \\
\hline & 0.45 & & SNF & $1.8,2.4,3.6 \%$ & $1.8 \%$ & $0,1.8 \%$ \\
\hline & 0.45 & & PE1 & $1.0,1.25,2.0,2.5 \%$ & $1.25 \%$ & $0,1.25 \%$ \\
\hline & 0.45 & & PE2 & $0.5,0.75,1.0 \%$ & $0.5 \%$ & $x$ \\
\hline
\end{tabular}

The maximum amount of P and SP corresponded to the maximum amount recommended by the producer of the admixture. The maximum content of admixture also did not exceed the saturation point, which was verified in preliminary studies.

This study was conducted on mortars, but due to the similarity of the rheology of mortars and concrete mixes, it can also be used to design the workability of a concrete mix.

\subsection{Materials and the Composition}

The composition and selected physical properties of the raw and ground CFA used in this research are compiled in Table 3. Blaine specific surface was tested according to [34].

Table 3. Chemical composition of CFA.

\begin{tabular}{|c|c|c|c|c|c|c|c|c|c|c|c|c|c|c|}
\hline \multirow{2}{*}{ CFA } & \multirow{2}{*}{ LOI } & \multirow{2}{*}{$\mathrm{SiO}_{2}$} & \multirow{2}{*}{$\mathrm{Al}_{2} \mathrm{O}_{3}$} & \multirow{2}{*}{$\mathrm{Fe}_{2} \mathrm{O}_{3}$} & \multirow{2}{*}{$\mathrm{CaO}$} & \multirow{2}{*}{$\mathrm{SO}_{3}$} & \multirow{2}{*}{$\mathrm{K}_{2} \mathrm{O}$} & \multirow{2}{*}{$\mathrm{Na}_{2} \mathrm{O}$} & \multirow{2}{*}{$\mathrm{CaO}_{\mathrm{w}}$} & \multirow{2}{*}{$\begin{array}{c}\text { Bulk } \\
\text { Density } \\
{\left[\mathrm{kg} / \mathrm{m}^{3}\right]}\end{array}$} & \multicolumn{2}{|c|}{ Fineness } & \multicolumn{2}{|c|}{$\begin{array}{c}\text { Blaine Specific } \\
\text { Surface }[34] \\
{\left[\mathrm{cm}^{2} / \mathrm{g}\right]}\end{array}$} \\
\hline & & & & & & & & & & & Raw & $\begin{array}{c}\text { Ground } \\
\text { G }\end{array}$ & Raw & $\begin{array}{c}\text { Ground } \\
\text { G }\end{array}$ \\
\hline A & 2.56 & 33.47 & 19.19 & 5.37 & 31.18 & 4.33 & 0.11 & 0.31 & 3.43 & 1098 & 36.4 & 23 & 2860 & 3500 \\
\hline B & 2.12 & 40.98 & 19.00 & 4.25 & 25.97 & 3.94 & 0.14 & 0.13 & 1.07 & 1028 & 46.3 & 20.8 & 2370 & 3520 \\
\hline $\mathrm{C}$ & 2.67 & 45.17 & 20.79 & 4.58 & 20.6 & 2.5 & 0.19 & 0.23 & 1.18 & 960 & 57.2 & 16.7 & 1900 & 3700 \\
\hline
\end{tabular}

Ground CFA was created by subjecting raw CFA to a grinding process in a laboratory ball mill. The residue on the $45 \mu \mathrm{m}$ sieve was taken as the measure of grinding. Due to its coarse granulation and 
value of fineness (minimum, 36\%; average, 50\%), the tested CFA did not meet the basic requirements set by the ASTM C618 standard [35] (retention on a $45 \mu \mathrm{m}$ sieve at a maximum of 34.0\%) and PN-EN 450-1 standard [36] (retention on a $45 \mu \mathrm{m}$ sieve at a maximum of $40 \%$ ). The other requirements for the CFA composition were, however, met. Fluctuations in the chemical composition and properties of the ash are significant, especially the amount of $\mathrm{CaO}, \mathrm{SO}_{3}$, and $\mathrm{Na}_{2} \mathrm{O}$. However, it should be noted that CFA is characterised by a relatively low changeability in the amount of $\mathrm{SiO}_{2}$ and $\mathrm{Al}_{2} \mathrm{O}_{3}$ and a low loss on ignition. The X-ray diffraction (XRD) pattern of CFA is presented in Figure 1. The differential thermal analysis (DTA) pattern of CFA is presented in Figures 2-4. The cumulative distribution of ash grain size is presented in Figure 5 . This ash contains above $25 \%$ reactive silica and above $10 \%$ reactive calcium oxide, which shapes its pozzolano-hydraulic properties. The results of the supplementary tests in terms of phase composition and granulation confirm the above-mentioned observations on the usefulness of calcareous fly ash as a pozzolan-hydraulic component of cement for batches of materials with different phase compositions (see the diffractograms and thermograms in Figures 1-4) and variable particle sizes within the fluctuations shown during intensive monitoring, as shown in Figure 5. Observations of calcareous fly ash using scanning electron microscopy showed the presence of grains with a spherical shape and a smooth surface, as well as irregularly shaped porous grains, as displayed in Figures 6-8.

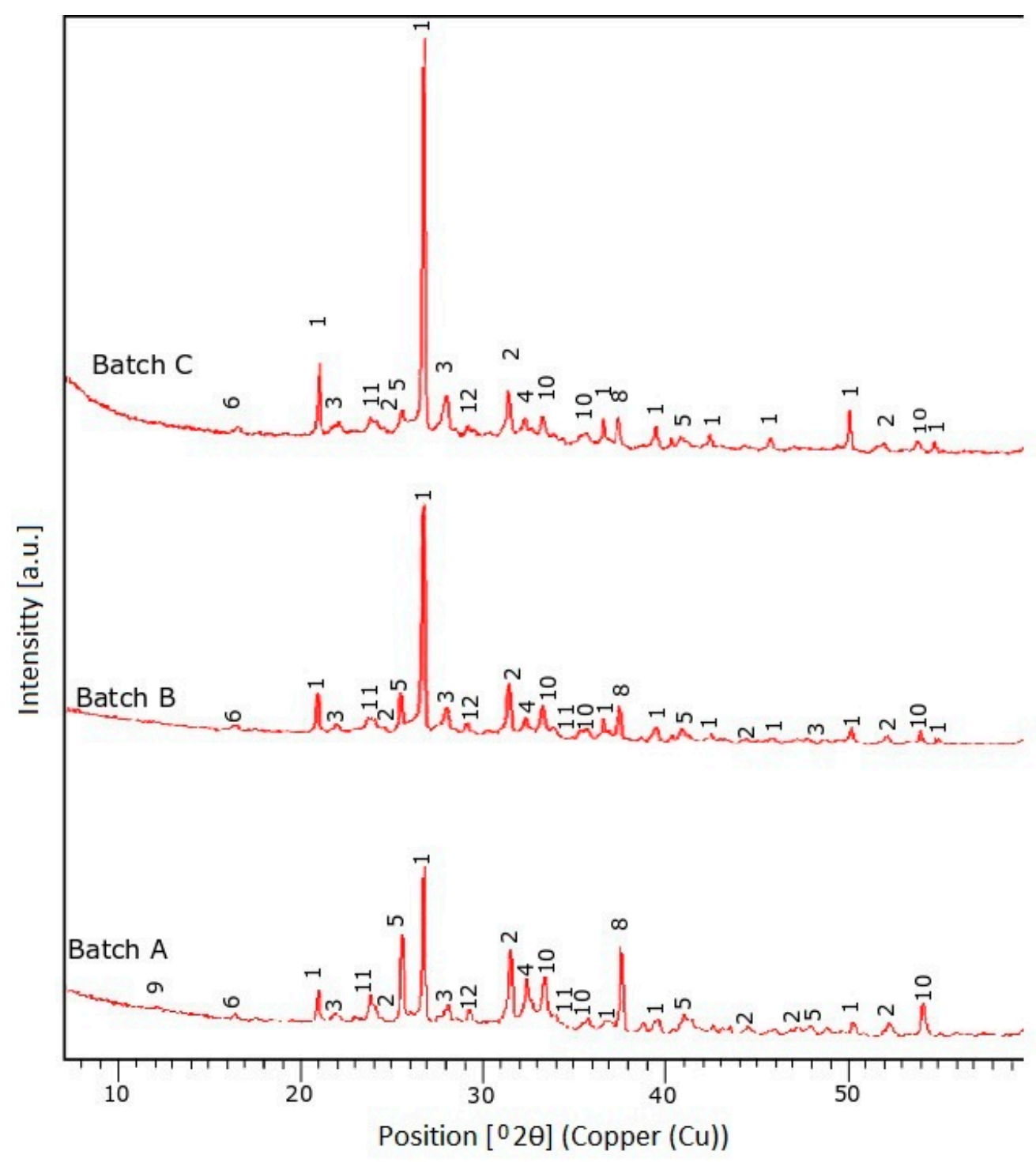

Figure 1. Cont. 


\begin{tabular}{|c|c|c|c|c|c|c|c|c|c|c|c|c|c|}
\hline & \multicolumn{13}{|c|}{ Quantative Phase Composition of CFA } \\
\hline & \multicolumn{13}{|c|}{ Component share [\% by mass] } \\
\hline & 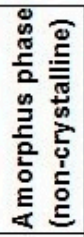 & 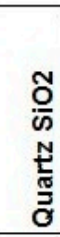 & 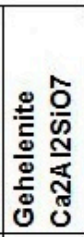 & 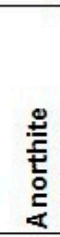 & 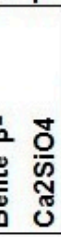 & 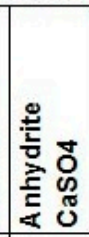 & 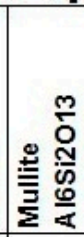 & 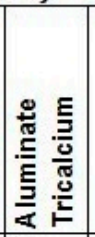 & 용 & 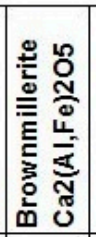 & 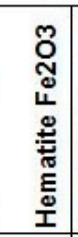 & 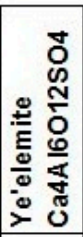 & $\begin{array}{l}\frac{ \pm}{ \pm} \\
\frac{0}{J} \\
0\end{array}$ \\
\hline \begin{tabular}{|l|} 
Symbol in \\
diffractograms
\end{tabular} & - & 1 & 2 & 3 & 4 & 5 & 6 & 7 & 8 & 9 & 10 & 11 & 12 \\
\hline Batch A & 41.1 & 18.2 & 7.8 & 6.3 & 6.5 & 5.8 & 3.4 & 5.8 & 3.4 & 0.5 & 0.5 & 0.4 & $<<0.1$ \\
\hline Batch B & 52.8 & 16.8 & 7 & 8.8 & 5.5 & 46 & 6.1 & 5.6 & 1.5 & 0.6 & 0.5 & 0.3 & $3<0.1$ \\
\hline Batch C & 43.5 & 22.2 & 7 & 9.8 & 2.9 & 3.4 & 8.1 & 1.5 & 1.2 & 0.9 & 0.5 & 0.2 & $2<0.1$ \\
\hline
\end{tabular}

Figure 1. The X-ray diffraction (XRD) pattern of CFA batch A, B, C.

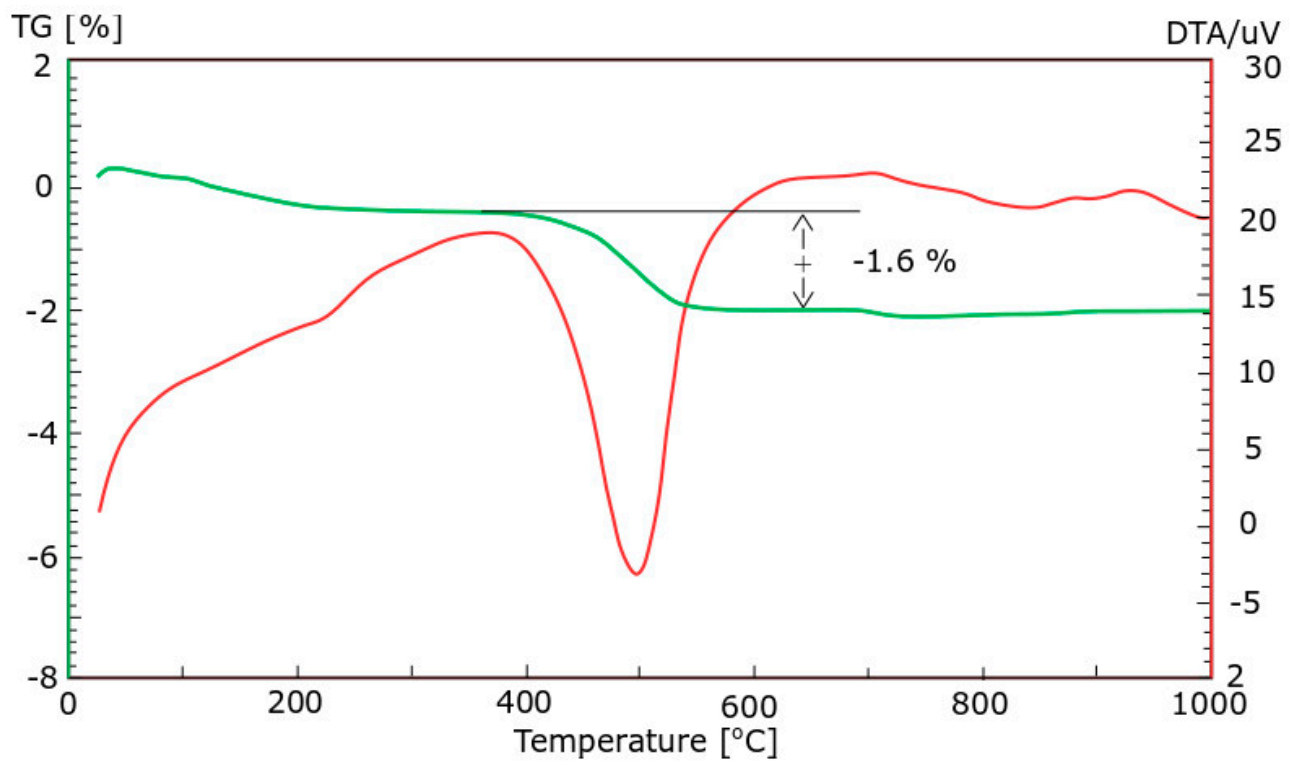

Figure 2. The differential thermal analysis (DTA) pattern of CFA batch A.

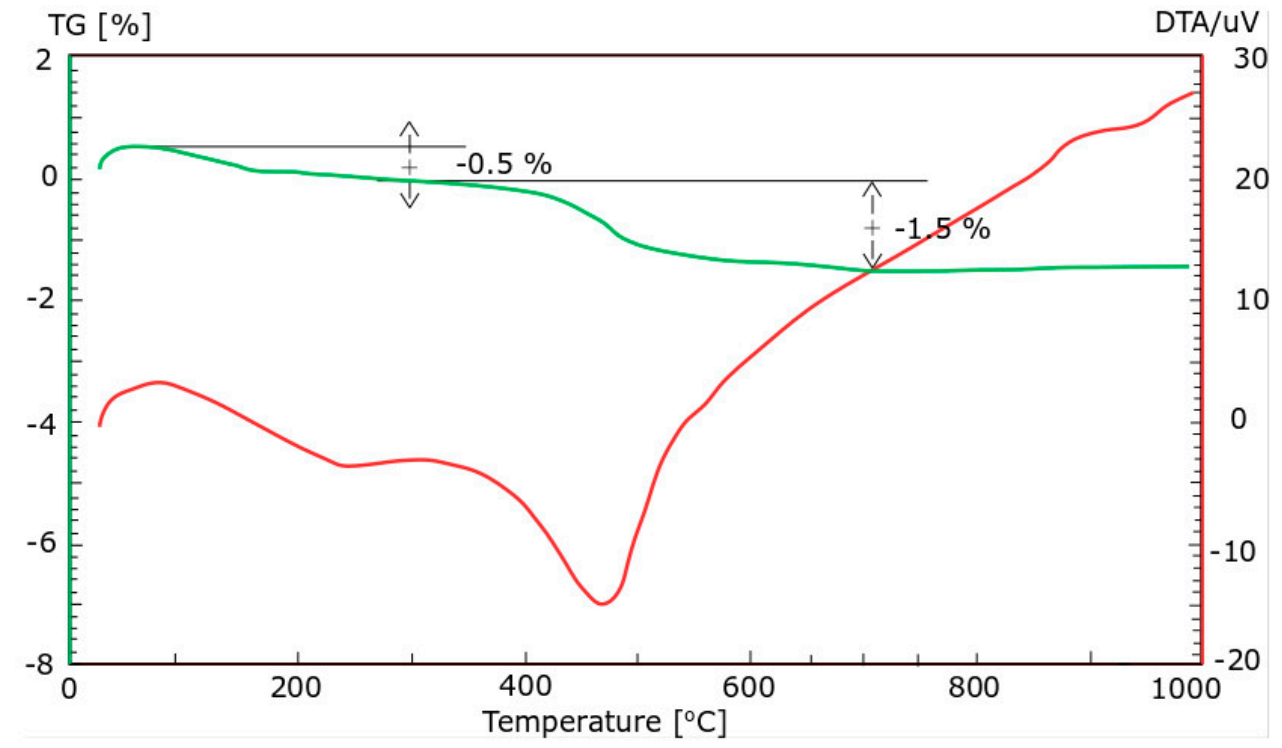

Figure 3. The differential thermal analysis (DTA) pattern of CFA batch B. 


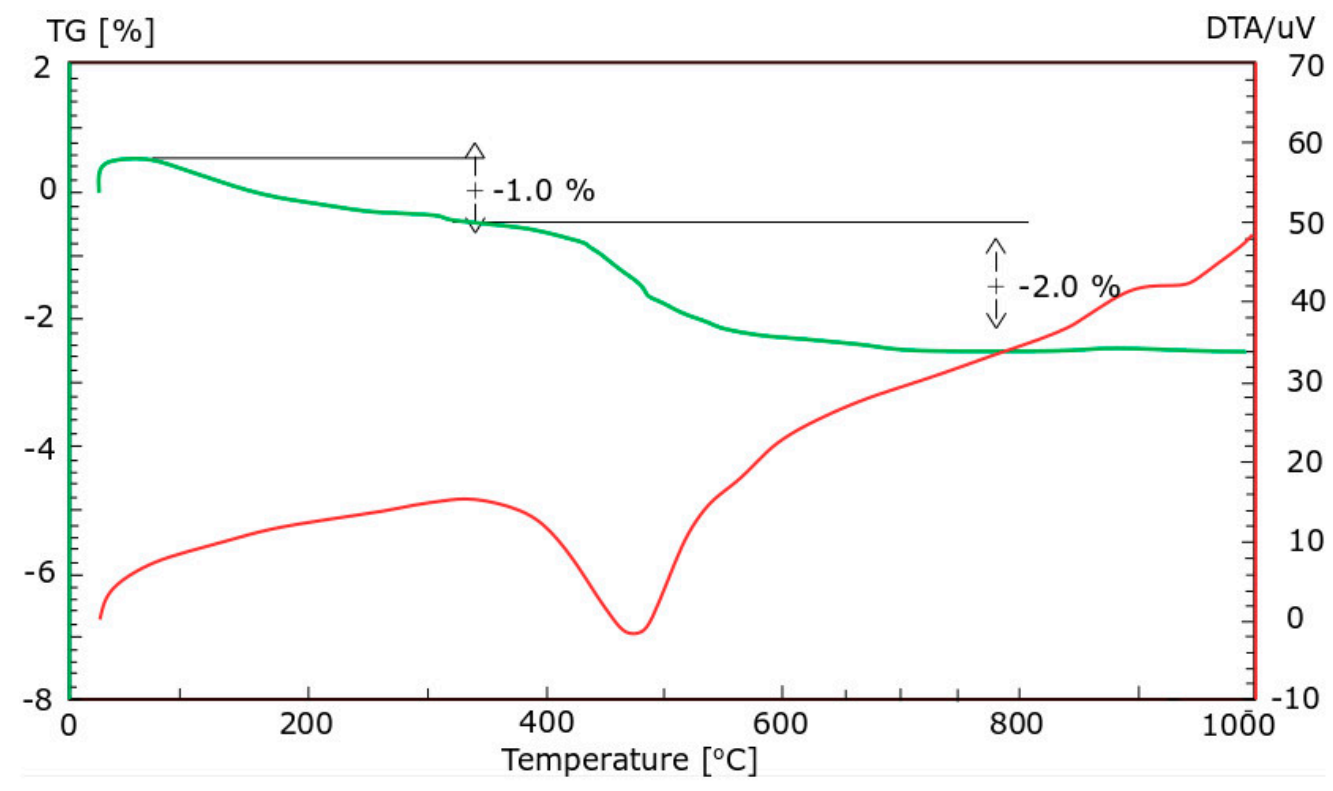

Figure 4. The differential thermal analysis (DTA) pattern of CFA batch C.

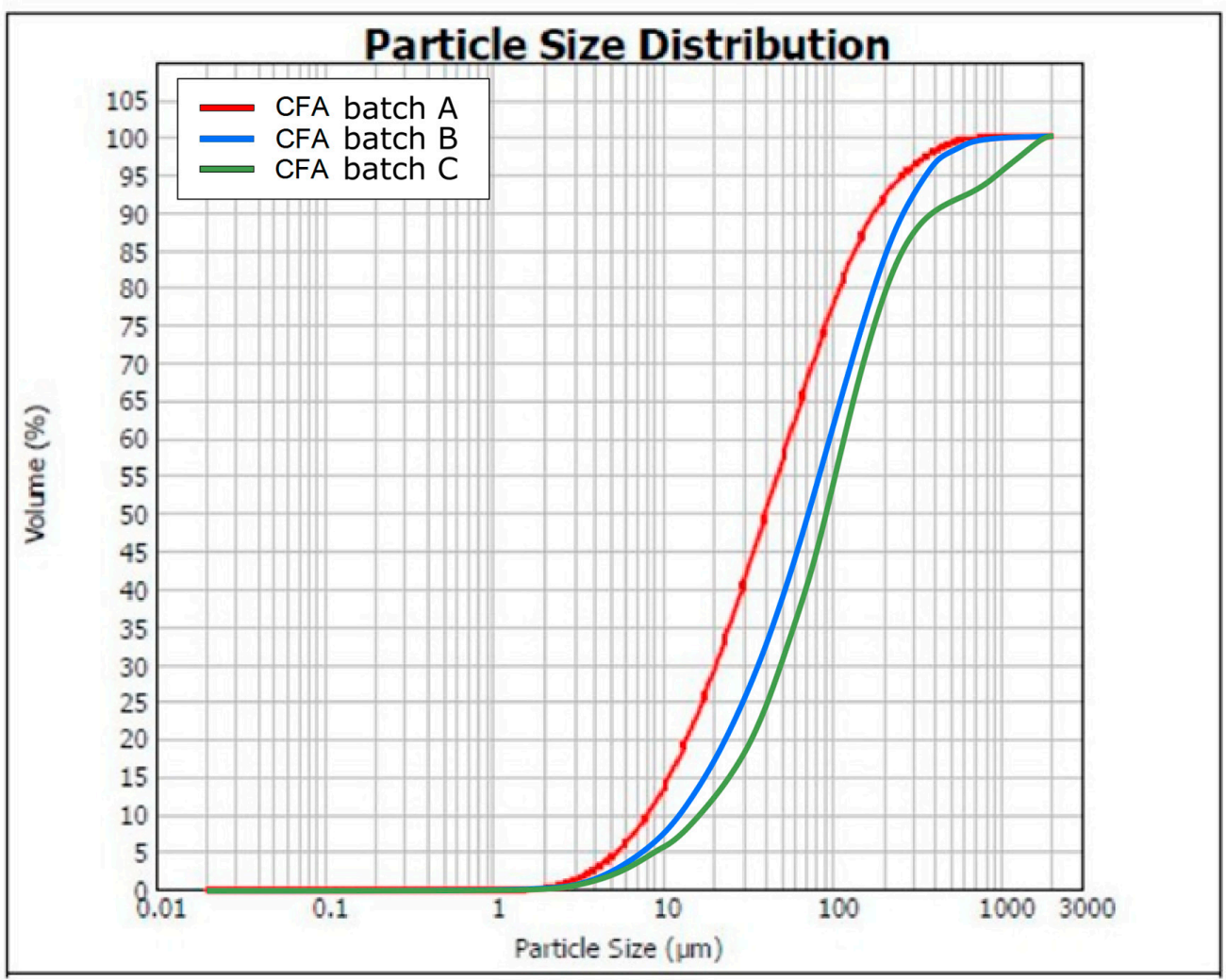

Figure 5. Cumulative distribution of ash grain size of CFA batch A, B, C.

After processing by grinding, the requirement of fineness under $34 \%$ is always met, and the Blaine specific surface is $3500-3700 \mathrm{~cm}^{2} / \mathrm{g}$. The water demand of the tested CFA is high. Replacing $20 \%$ of the cement with CFA causes the water demand to increase from $8 \%$ to $12 \%$ (on average, 10\%) (the test procedure according to PN EN 450-1 [36]). Processing of the CFA by grinding causes the water demand to decrease. Replacing $20 \%$ of the cement with ground CFA causes the water demand to increase from $2 \%$ to $6 \%$ (on average, $4 \%$ ). 
The properties used for P and SP are presented in Table 4. The properties of the CEM I 42.5 cement used in this research are presented in Table 5. The mortar proportions are shown in Table 6. In order to eliminate the influence of the type and grading of sand on the rheological properties of the mortars, normal sand ( $2 \mathrm{~mm}$ maximum with a bulk density of $2.65 \mathrm{~g} / \mathrm{cm}^{3}$, according to PN-EN 196-1 [37]) was used. The grading curve of the normal sand is presented in Figure 9 . The proportions of the mortar mixture were based on standard mortar proportioning according to PN-EN 196-1 [37] but with the w/b ratio changed to 0.45 or 0.55 .

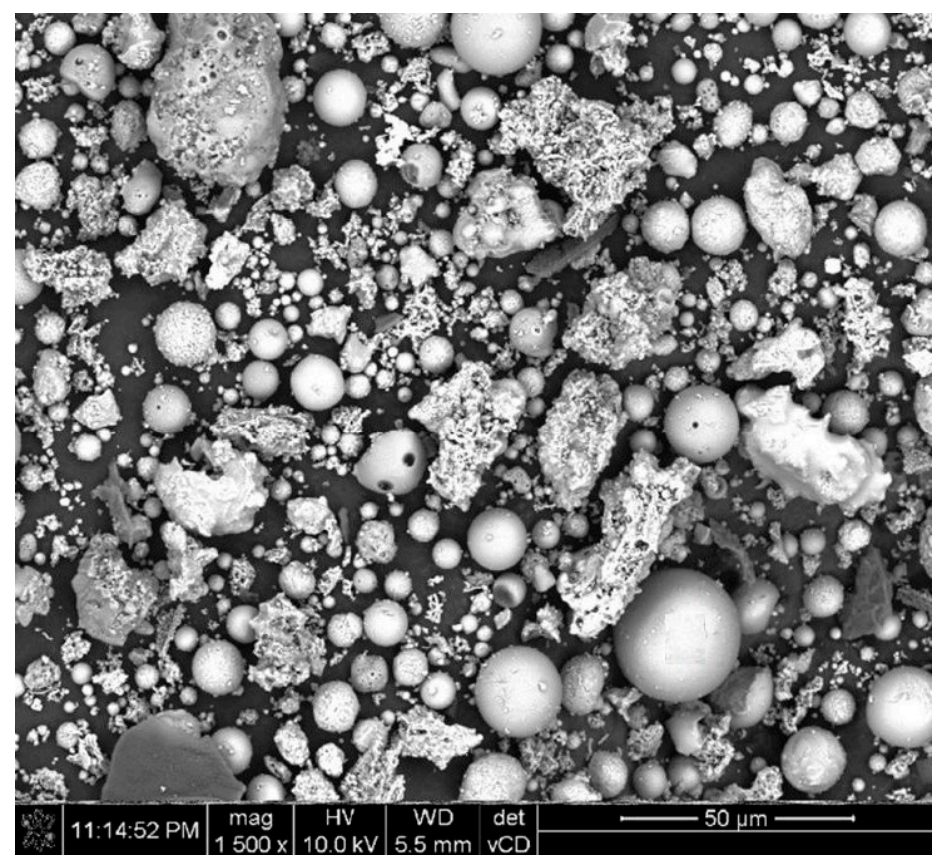

Figure 6. Morphology of calcareous fly ash grains batch A (magnification of 1500 times).

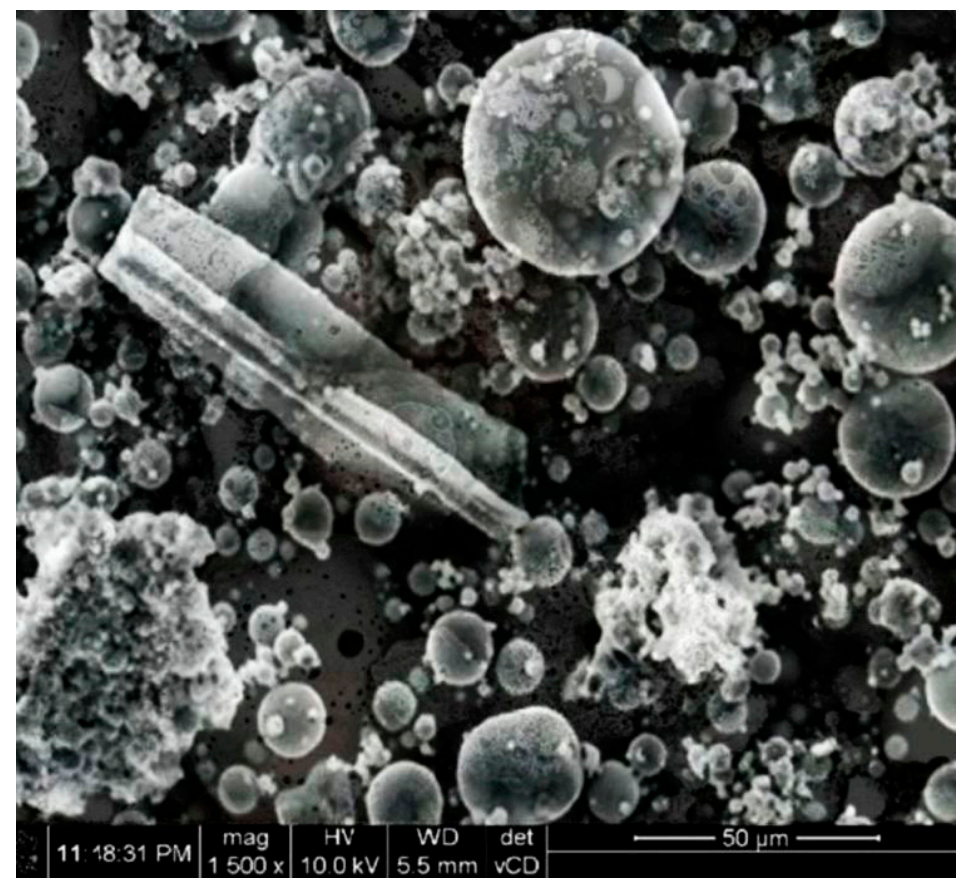

Figure 7. Morphology of calcareous fly ash grains batch B (magnification of 1500 times). 


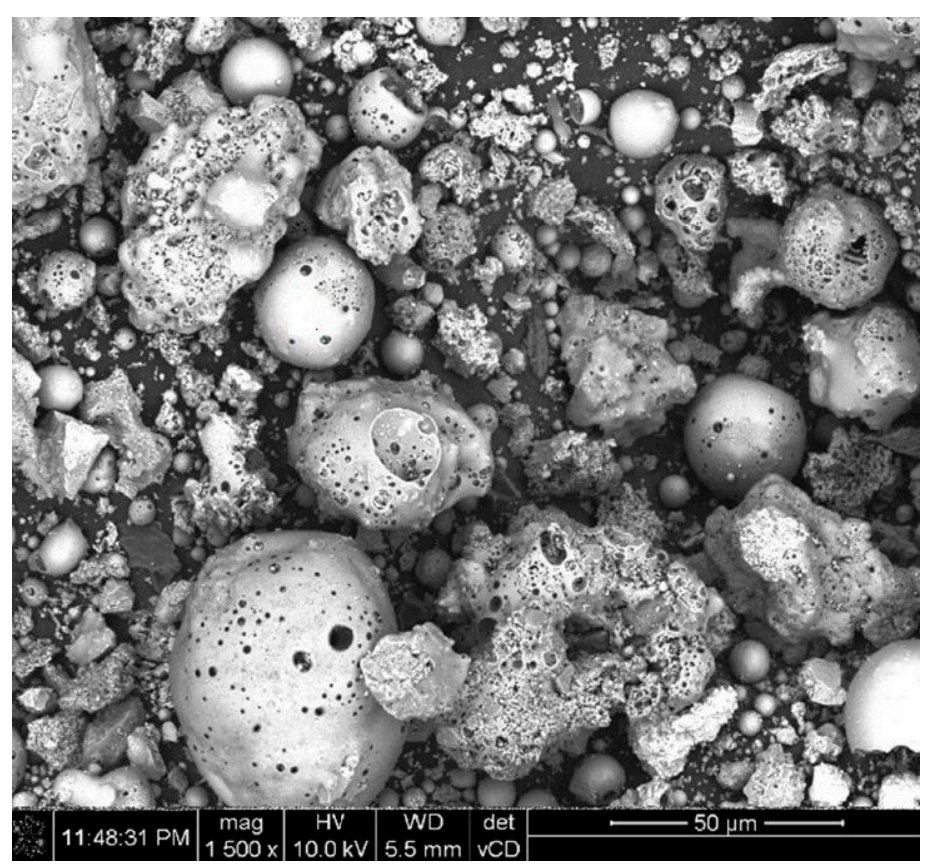

Figure 8. Morphology of calcareous fly ash grains batch C (magnification of 1500 times).

Table 4. The type, chemical base, density and volume of chemical admixtures. Date obtained from the manufacturer of admixture.

\begin{tabular}{|c|c|c|c|c|}
\hline \multicolumn{2}{|c|}{$\begin{array}{l}\text { Symbol of } \\
\text { Admixture }\end{array}$} & Chemical Base & $\begin{array}{c}\text { Density at } 20^{\circ} \mathrm{C}, \\
{\left[\mathrm{g} / \mathrm{cm}^{3}\right]}\end{array}$ & $\begin{array}{c}\text { Maximum } \\
\text { Recommended } \\
\text { Dosage, [\% b.m] }\end{array}$ \\
\hline \multirow[b]{2}{*}{$\mathrm{P}$} & P1 & lignosulfonates & $1.00+/-0.01$ & $0.5 \%$ \\
\hline & P2 & $\begin{array}{l}\text { iminodietanol, bis ethanol, } \\
\text { phosphate (V) tri butyl acetate, } \\
\text { formaldehyde, methanol, } \\
\text { (Z)-octadec-9-enyloamine }\end{array}$ & $1.07+/-0.01$ & $0.5 \%$ \\
\hline \multirow{4}{*}{ SP } & PE1 & polycarboxylate ether & $1.07+/-0.02$ & $2.5 \%$ \\
\hline & PE2 & polycarboxylate ether & $1.07+/-0.02$ & $1.0 \%$ \\
\hline & SMF & melamine sulfonates & $1.20+/-0.03$ & $2.3 \%$ \\
\hline & SNF & naphthalene sulfonate & $1.15+/-0.03$ & $3.6 \%$ \\
\hline
\end{tabular}

Table 5. Properties of cement CEM I 42.5. Data obtained from the cement producer.

\begin{tabular}{ccccccccccc}
\hline $\begin{array}{c}\mathrm{SiO}_{2} \\
{[\%]}\end{array}$ & $\begin{array}{c}\mathrm{Al}_{2} \mathrm{O}_{3} \\
{[\%]}\end{array}$ & $\begin{array}{c}\mathrm{Fe}_{2} \mathrm{O}_{3} \\
{[\%]}\end{array}$ & $\begin{array}{c}\mathrm{CaO} \\
{[\%]}\end{array}$ & $\begin{array}{c}\mathrm{SO}_{3} \\
{[\%]}\end{array}$ & $\begin{array}{c}\mathrm{Na}_{2} \mathrm{O}_{\mathrm{e}} \\
{[\%]}\end{array}$ & $\begin{array}{c}\mathrm{C}_{3} \mathrm{~S} \\
{[\%]}\end{array}$ & $\begin{array}{c}\mathrm{C}_{2} \mathrm{~S} \\
{[\%]}\end{array}$ & $\begin{array}{c}\mathrm{C}_{3} \mathbf{A} \\
{[\%]}\end{array}$ & $\begin{array}{c}\mathrm{C}_{4} \mathrm{AF} \\
{[\%]}\end{array}$ & $\begin{array}{c}\text { Spec. Surf., [34] } \\
{\left[\mathrm{cm}^{2} / \mathrm{g}\right]}\end{array}$ \\
\hline 20.5 & 4.89 & 2.85 & 63.3 & 2.76 & 0.73 & 65 & 10 & 8.1 & 8.7 & 3500 \\
\hline
\end{tabular}

Table 6. Composition of mortars for testing the rheological properties.

\begin{tabular}{cc}
\hline Constituent & Amount, [g/batch] \\
\hline Cement & $450 / 405 / 360 / 315$ \\
Calcium Fly Ash & $-/ 45 / 90 / 135$ \\
w/(c + CFA) & $0.45 / 0.55$ \\
Water & $202.5 / 247.5$ \\
Standard sand & 1350 \\
\hline
\end{tabular}




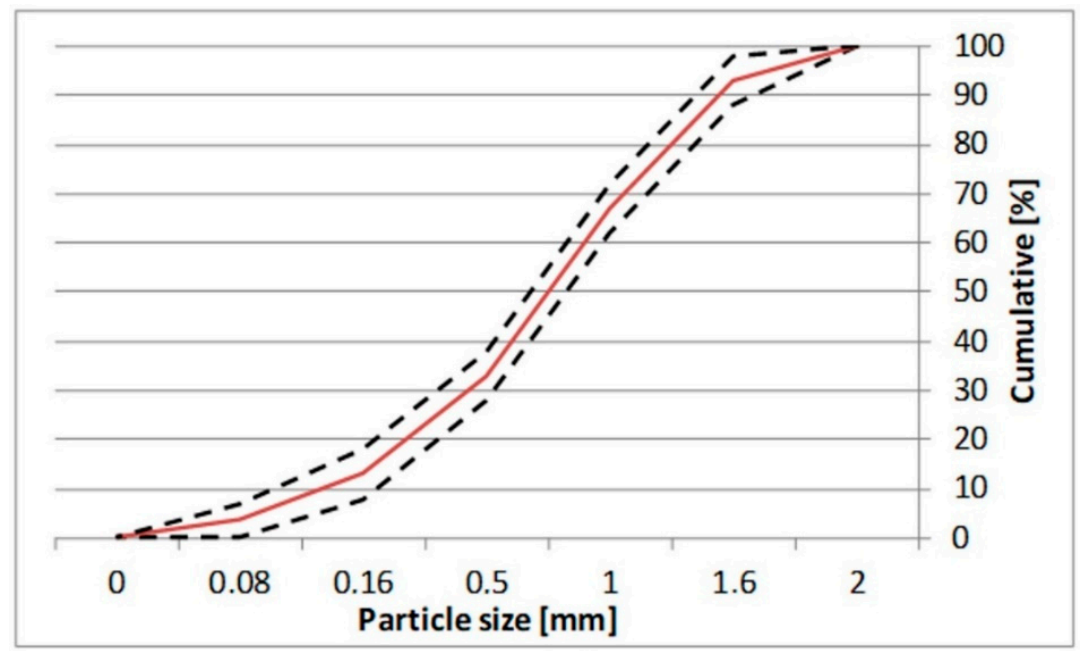

Figure 9. The grading curve of normal sand [34].

\subsection{Testing Effectiveness of the Plasticizer and Superplasticizer Action}

\subsubsection{Rheological Properties}

The rheological behaviour of mortar and concrete is commonly described by the Bingham model using the parameters of yield value and plastic viscosity.

The yield value determines the shear stress necessary for initiating flow. When the shear stress is higher than the yield value, the mixture starts to flow at a speed inversely proportional to the plastic viscosity. The yield value controls the workability of ordinary fresh concrete, while the role of plastic viscosity is secondary. In the case of self-compacting concrete characterized by a low yield value, the plastic viscosity determines the flowability, stability, and ability to self-deaerate. Problems with the rheology of mortars and concretes are discussed in detail in [28,38,39].

The mortars for testing the rheological properties were prepared according to PN-EN 196-1 [37], and the mixer and mixing procedures were compliant with PN-EN 196-1 [34]. CFA was added together with cement, and the admixtures were added to water (PE) and delayed for $30 \mathrm{~s}$ (P, SNF, and SMF). After the end of mixing, the mortar samples were transferred to a Viskomat NT rotational rheometer. The rheological parameters $\mathrm{g}(\mathrm{Nm})$ and $\mathrm{h}(\mathrm{Nm} \mathrm{s})$, corresponding to yield value and plastic, were then determined. The values of $g$ and $h$ can be presented in physical units, but the measurement constants of the rheometer have to be defined. According to [29], in an apparatus like the one used in this work, $\tau_{\mathrm{o}}=7.9 \mathrm{~g}$ and $\eta_{\mathrm{pl}}=0.78 \mathrm{~h}$. However, since the rheometer constants were not verified, the results are presented as $g$ and $h$. The mean relative errors of determination of the rheological parameters $g$ and $h$ of the mortars containing CFA were, respectively, $4.4 \%$ and $4.5 \%$, which are identical to other studies. This proves that the Bingham model is acceptable for describing the rheological properties of mortars with CFA and P or SP. The general basis and rules for rheological measurements are detailed in [38,39]. The tested mortars were prepared and stored between measurements under conditions that allowed its temperature to remain at $20^{\circ} \mathrm{C}$. During the measurements, the required temperature was maintained with an automatic thermostatic controller.

\subsubsection{Air Content}

The air content in the mortar was determined by PN-EN 1015-7 [40].

\subsubsection{Heat of Hydration}

The heat of hydration for the cement-CFA-admixture systems was determined using an isothermal microcalorimeter (TamAir). This apparatus measures the amount of heat (in J/g) that is emitted under 
isothermal conditions during binder hydration (CFA and CEM I) from the moment of its contact with water and admixture in relation to an inert referential sample with an analogous heat capacity. The water-binder ratio $(\mathrm{w} / \mathrm{b})$ of the tested cement paste was 0.45 (P, SMF) or 0.55 (SNF, PE). This measurement was conducted on a binder sample weighting $5 \mathrm{~g}$, mixed with $2.25 \mathrm{~g}$ or $2.75 \mathrm{~g}$ of water. During the measurement, the temperature of the cement paste was $20^{\circ} \mathrm{C}$. The measurement of the heat of hydration lasted $12 \mathrm{~h}$.

\section{Results and Discussion}

The influence of $\mathrm{P}$ and SP on the rheological properties of CFA mortars is shown in Figures 10-13, and their influence on the air content and heat of hydration is shown in Tables 7 and 8, respectively.

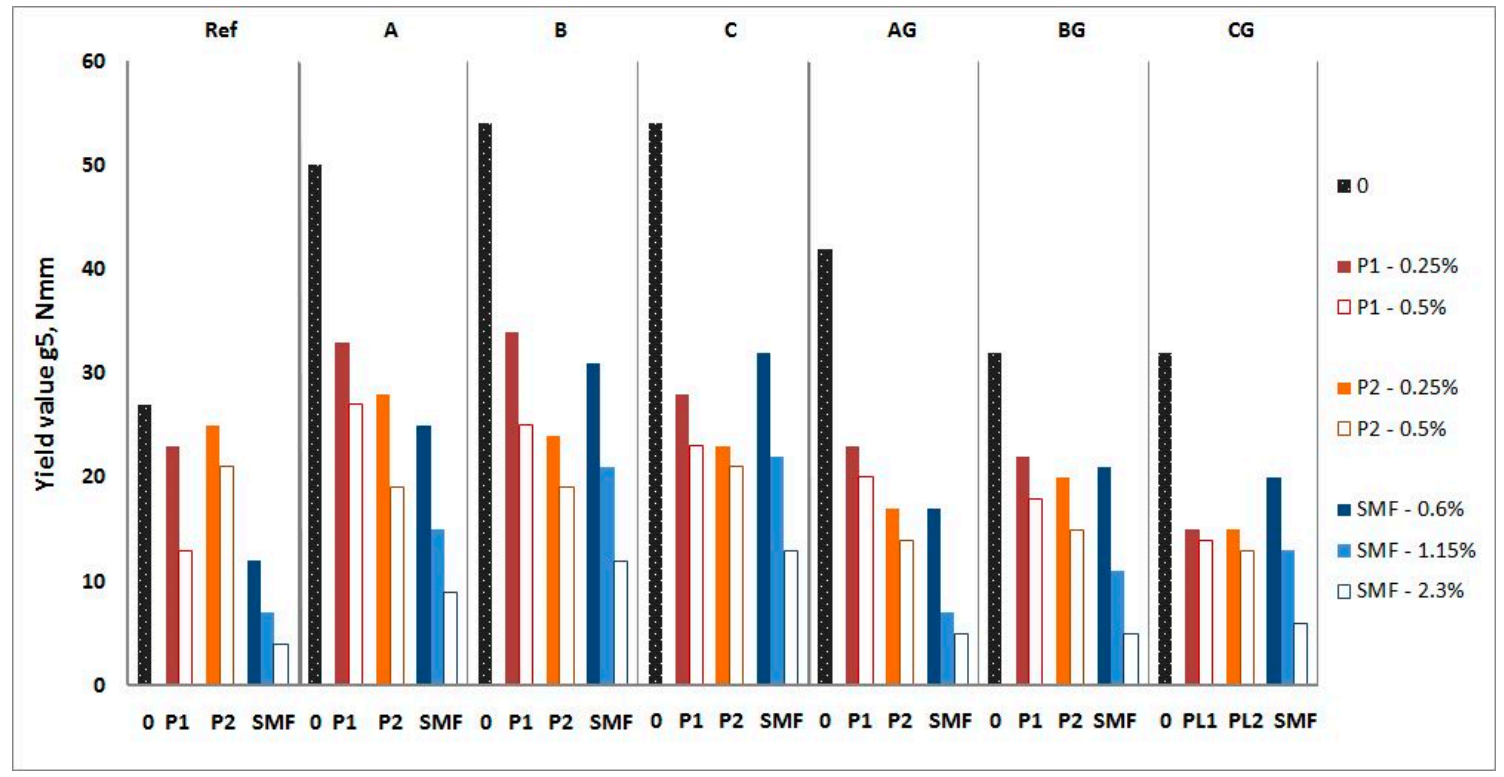

(a) after $5 \mathrm{~min}$

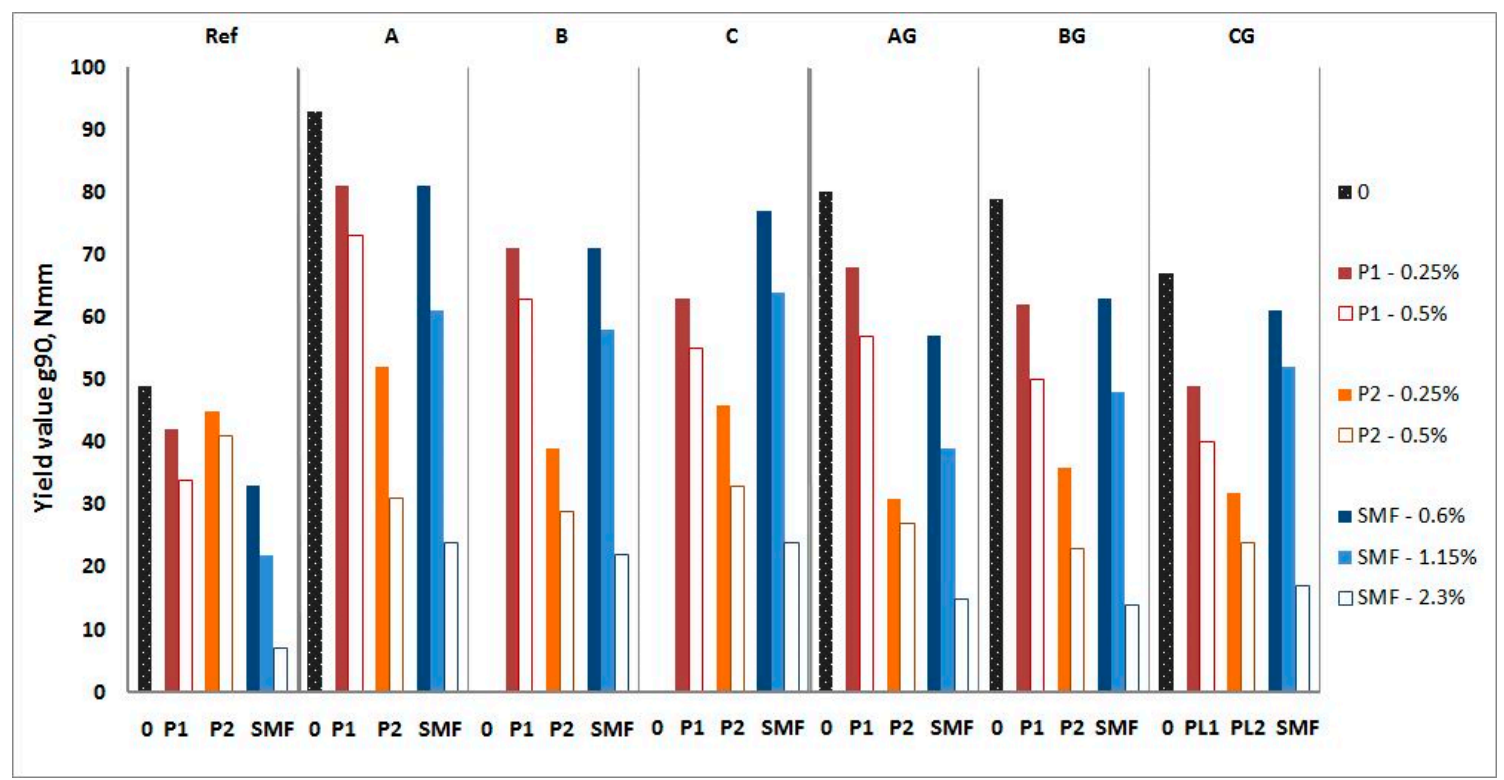

(b) after $90 \mathrm{~min}$

Figure 10. Influence of $\mathrm{P} 1$ and $\mathrm{P} 2$ and SMF on yield value $\mathrm{g}$ of mortars with raw and ground CFA. (a) after $5 \mathrm{~min}$; (b) after $90 \mathrm{~min}$. 


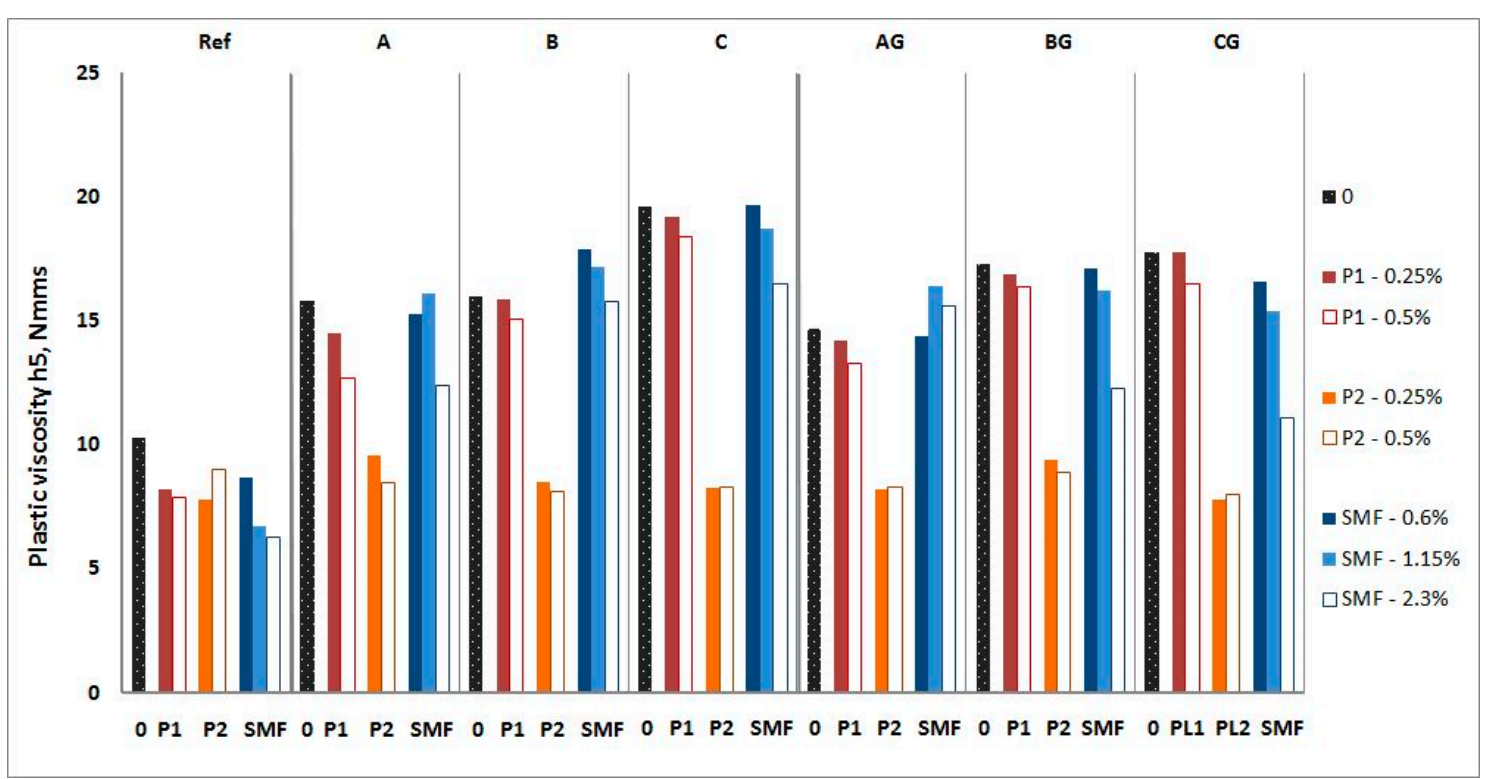

(a) after $5 \mathrm{~min}$

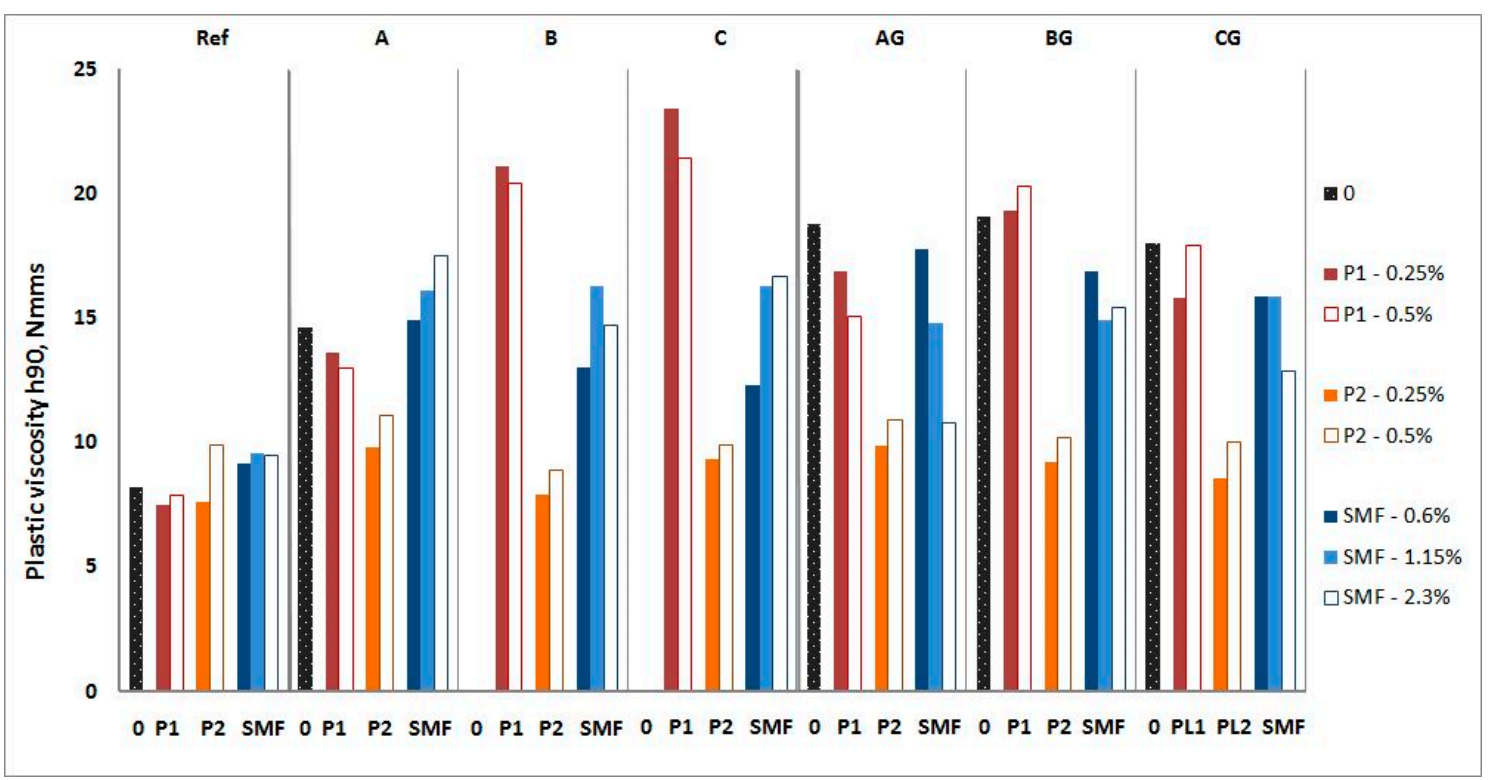

(b) after $90 \mathrm{~min}$

Figure 11. Influence of $\mathrm{P} 1$ and $\mathrm{P} 2$ and SMF on plastic viscosity h of mortars with raw and ground CFA.

(a) after $5 \mathrm{~min}$; (b) after $90 \mathrm{~min}$.

The PL and SP used in this study liquefied the cement mortars containing CEM I without the addition of CFA. Studies have shown that the workability and stability of mortar are retained for a period of $90 \mathrm{~min}$. Thus, the admixtures used are compatible with the cement used in the study.

Adding raw CFA to mortars as a cement replacement causes a significant increase in the yield value $g$ and plastic viscosity $h$, depending on the type of CFA. The range of changes in the yield value $g$ of mortars increases over time, but the presence of CFA insignificantly affects changes in the plastic viscosity h over time. The nature of the influence of ground CFA on the rheological parameters of mortars is the same as that of raw CFA. It also worsens the workability of mortar, however, to a much lesser extent than raw CFA. The influence of CFA type and processing method is presented and discussed in $[14,19]$. 
In order to determine the significance of the influence of the compositional factors and their interactions on the rheological properties, an analysis of variance (ANOVA) was carried out using one-dimensional significance tests for the rheological parameters (g5, g90, h5, and h90) of the mortars with P and SP. The results are shown in Tables 9 and 10, which present the ANOVA with parameterization, sigma-restrictions, and a decomposition of the effective hypotheses. The ANOVA statistical analysis showed that the largest statistical effects on rheological parameters were yield value and plastic viscosity, regardless of the time at which the measurement was made, and the type of batch. The rheological parameters of the mortars with $\mathrm{P}$ were also affected by the type of batches and type of P. However, the rheological parameters of the mortars with SP were affected by the dosage of SP.

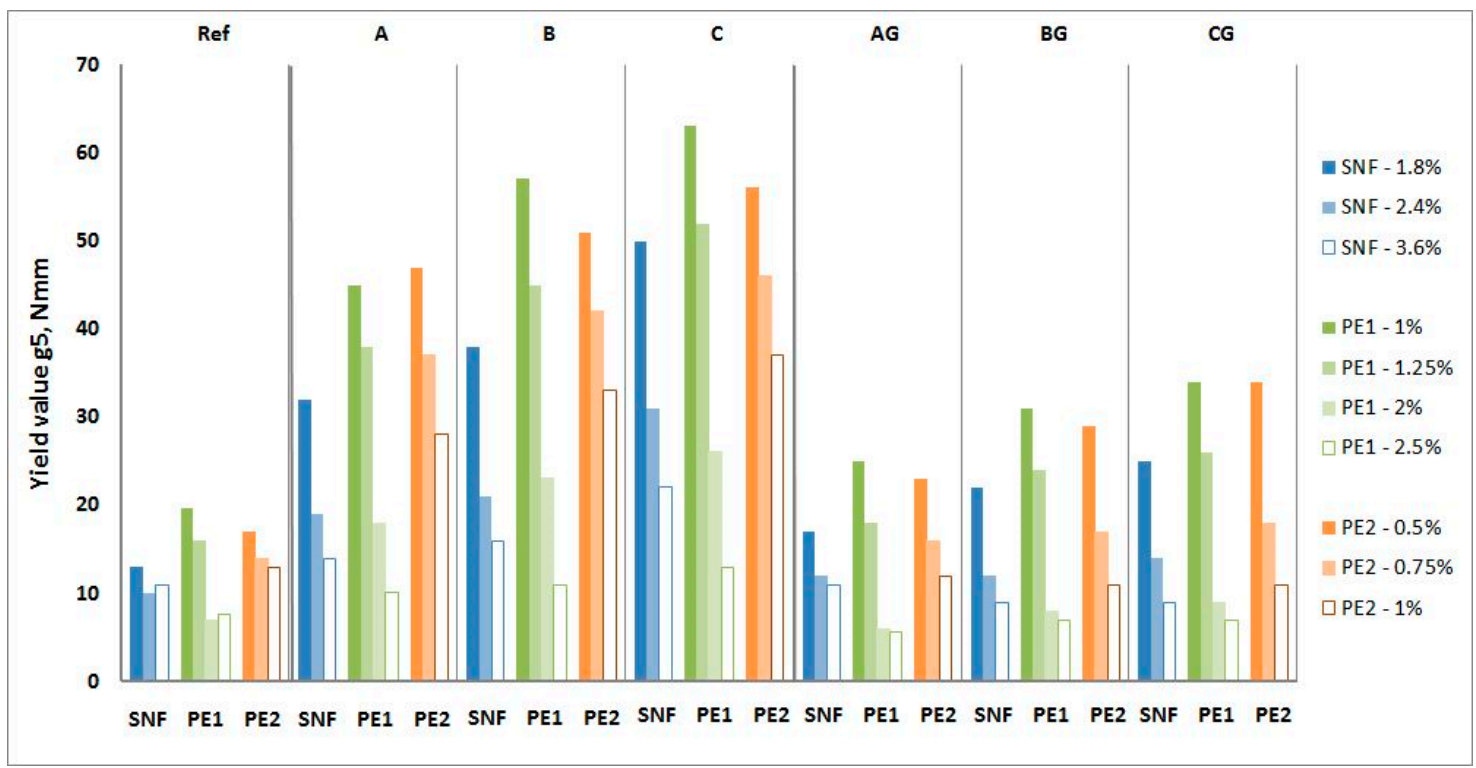

(a) after $5 \mathrm{~min}$

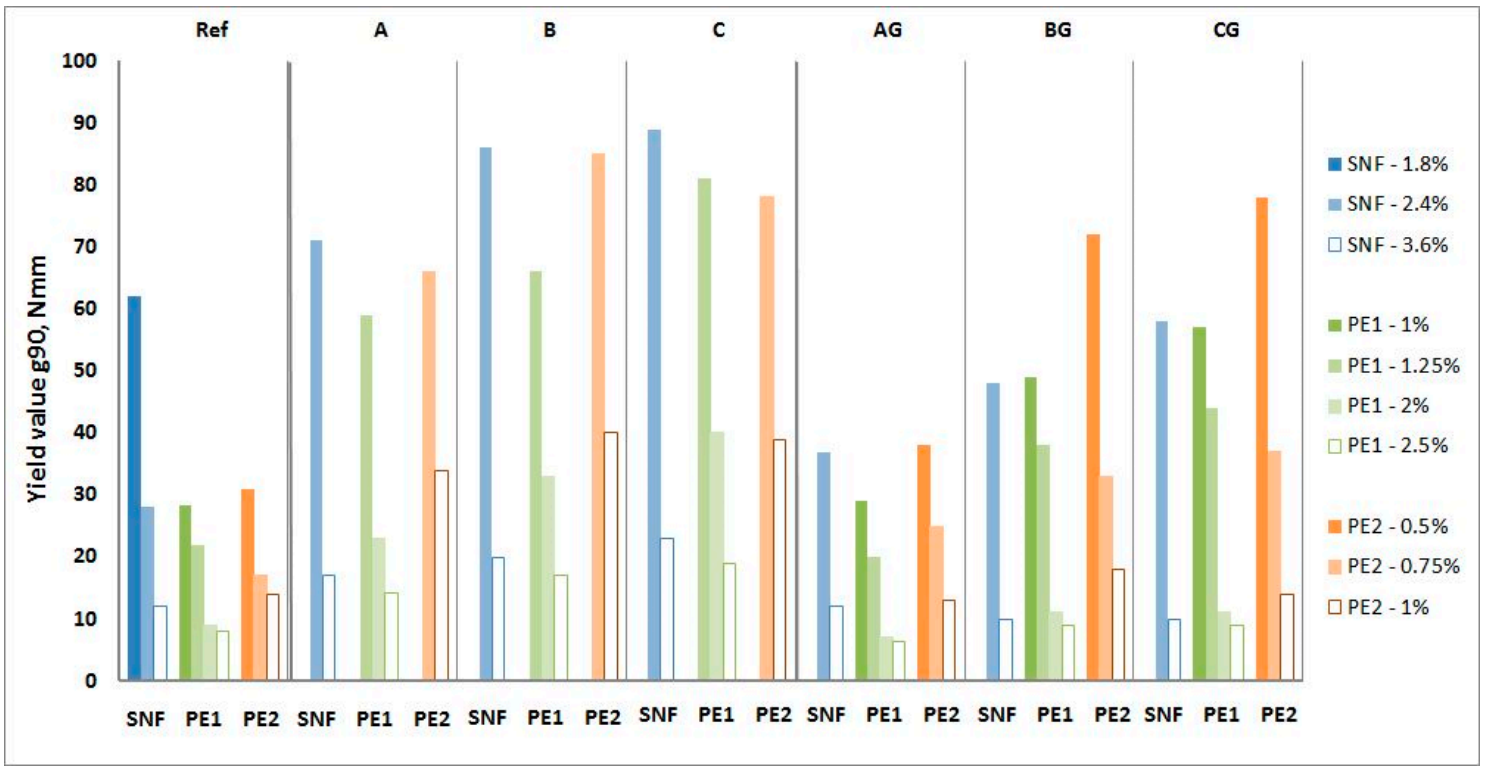

(b) after $90 \mathrm{~min}$

Figure 12. Influence of SNF, PE1 and PE2 on yield value g of mortars with raw and ground CFA. (a) after $5 \mathrm{~min}$; (b) after $90 \mathrm{~min}$. 


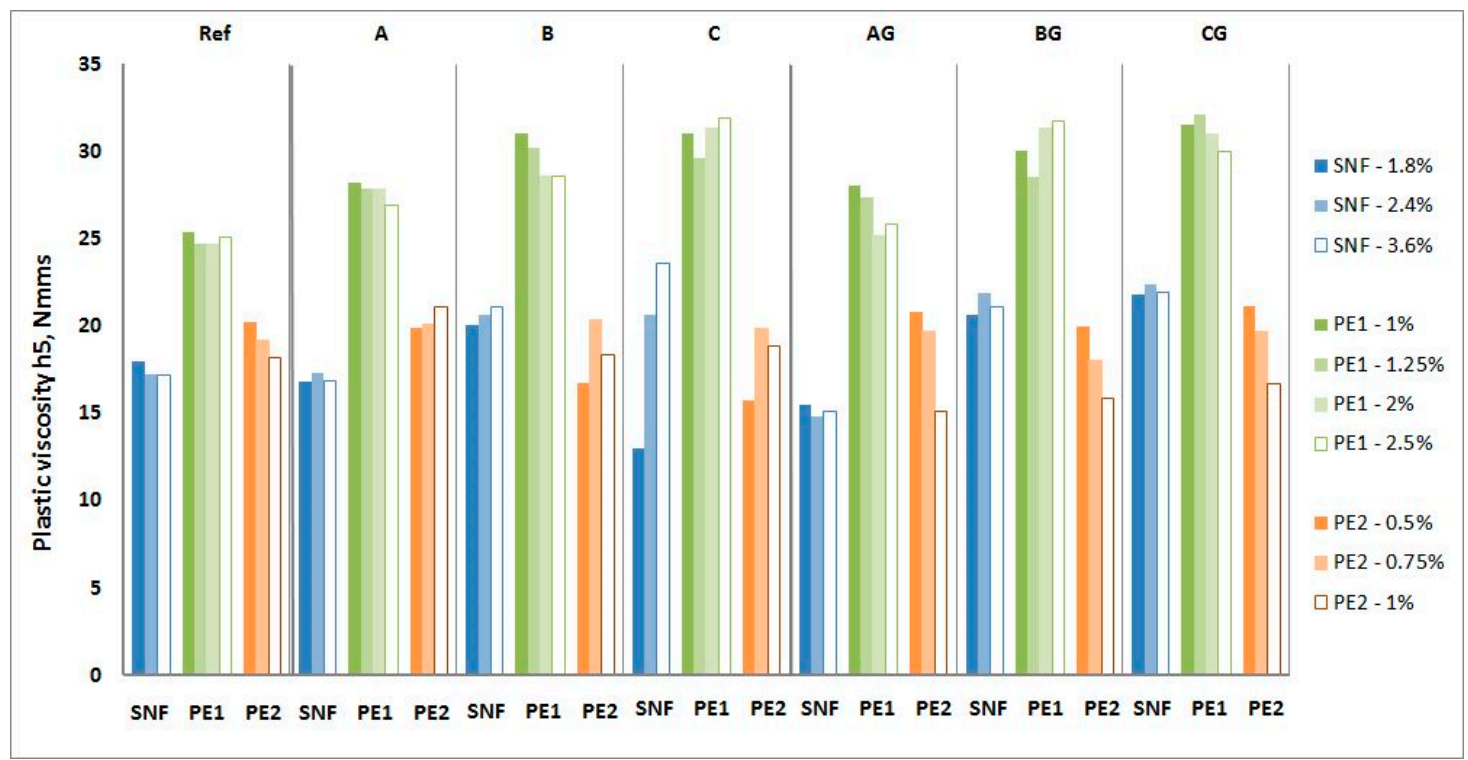

(a) after $5 \mathrm{~min}$

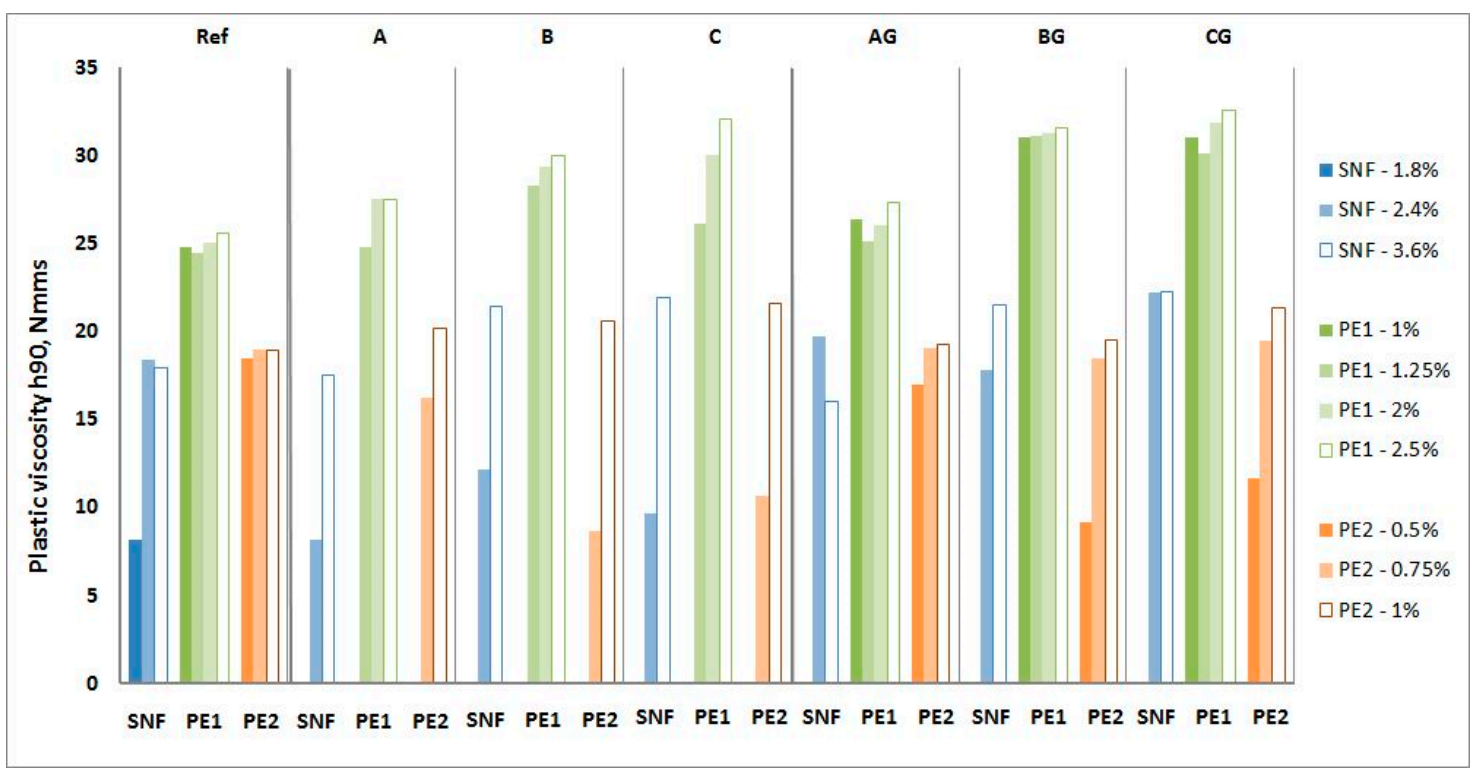

(b) after $90 \mathrm{~min}$

Figure 13. Influence of SNF, PE1 and PE2 on plastic viscosity h of mortars with raw and ground CFA. (a) after $5 \mathrm{~min}$; (b) after $90 \mathrm{~min}$.

Table 7. Influence of $\mathrm{P}$ and SP on air content in mortars with and without CFA.

\begin{tabular}{cccccccc}
\hline & \multicolumn{7}{c}{ Air Volume [\%] } \\
\cline { 2 - 7 } CFA & $\begin{array}{c}\text { without } \\
\text { Admixture }\end{array}$ & $\mathbf{0 . 2 5 \%} \mathbf{~ P 1}$ & $\mathbf{0 . 2 5 \%} \mathbf{~ P 2}$ & $\mathbf{1 . 1 5 \%}$ SMF & $\mathbf{1 . 8 \%}$ SNF & $\mathbf{1 . 2 5 \% ~ P E 1 ~}$ & $\mathbf{0 . 5 \%}$ PE2 \\
\hline CEM I & 5.2 & 4.6 & 19.0 & 2.5 & 13.5 & 2.8 & 9.5 \\
A & 2.8 & 2.4 & 16.6 & 3.3 & 13.1 & 2.4 & 13.2 \\
AG & 2.5 & 1.4 & 15.1 & 2.3 & 12.1 & 2.0 & 14.4 \\
B & 3.5 & 2.7 & 16.3 & 2.6 & 12.5 & 3.0 & 12.3 \\
BG & 2.9 & 2.4 & 17.5 & 1.2 & 11.9 & 4.0 & 11.2 \\
C & 4.2 & 2.1 & 17.2 & 2.7 & 12.9 & 2.0 & 11.6 \\
CG & 2.2 & 1.7 & 18.0 & 1.0 & 11.0 & 3.8 & 10.5 \\
\hline
\end{tabular}


Table 8. Heat of hydration of cement and CFA paste with P2 and SMF, SNF and PE1 [J/g] during $12 \mathrm{~h}$.

\begin{tabular}{|c|c|c|c|c|c|c|c|}
\hline \multicolumn{8}{|c|}{ Heat of Hydration, [J/g] } \\
\hline Sample & $10 \mathrm{~min}$ & $1.5 \mathrm{~h}$ & $12 \mathrm{~h}$ & Sample & $10 \mathrm{~min}$ & $1.5 \mathrm{~h}$ & $12 \mathrm{~h}$ \\
\hline \multicolumn{4}{|c|}{$\mathrm{w} / \mathrm{b}=0.55$} & \multicolumn{4}{|c|}{$\mathrm{w} / \mathrm{b}=0.45$} \\
\hline CEM I & 0.166 & 3.600 & 50.315 & CEM I & 0.177 & 3.619 & 51.764 \\
\hline CEM I + 1/2 max P2 & 0.011 & 1.588 & 20.520 & CEM I + 1/2 max SNF & -0.121 & 0.904 & 5.977 \\
\hline CEM I + 1/2 max SMF & 0.122 & 1.295 & 19.330 & CEM I + 1/2 max PE1 & -0.109 & 1.313 & 4.712 \\
\hline A & 0.850 & 7.336 & 47.157 & A & 0.753 & 6.909 & 47.032 \\
\hline $\mathrm{A}+1 / 2 \max \mathrm{P} 2$ & 0.885 & 6.697 & 32.721 & $\mathrm{~A}+1 / 2 \max \mathrm{SNF}$ & 0.627 & 5.854 & 21.384 \\
\hline $\mathrm{A}+1 / 2 \max \mathrm{SMF}$ & 0.852 & 6.277 & 34.699 & $\mathrm{~A}+1 / 2 \max$ PE1 & 0.650 & 4.583 & 14.576 \\
\hline AG & 1.433 & 9.018 & 49.557 & AG & 1.230 & 8.596 & 69.799 \\
\hline $\mathrm{AG}+1 / 2 \max \mathrm{P} 2$ & 1.252 & 7.032 & 35.273 & $\mathrm{AG}+1 / 2 \max \mathrm{SNF}$ & 0.991 & 6.437 & 21.983 \\
\hline $\mathrm{AG}+1 / 2 \max \mathrm{SMF}$ & 1.297 & 7.139 & 36.311 & $\mathrm{AG}+1 / 2 \max$ PE1 & 1.034 & 6.101 & 18.514 \\
\hline B & 0.876 & 6.843 & 44.860 & B & 0.876 & 6.843 & 44.860 \\
\hline$B+1 / 2 \max P 2$ & 0.652 & 5.212 & 27.130 & $\mathrm{~B}+1 / 2 \max \mathrm{SNF}$ & 0.853 & 5.766 & 19.844 \\
\hline $\mathrm{B}+1 / 2 \max \mathrm{SMF}$ & 0.684 & 5.645 & 32.767 & $\mathrm{~B}+1 / 2$ max PE1 & 0.506 & 4.462 & 13.293 \\
\hline BG & 1.095 & 7.994 & 49.350 & BG & 1.095 & 7.994 & 49.350 \\
\hline $\mathrm{BG}+1 / 2 \max \mathrm{P} 2$ & 0.715 & 5.627 & 30.805 & $\mathrm{BG}+1 / 2 \max \mathrm{SNF}$ & 0.723 & 6.021 & 21.042 \\
\hline $\mathrm{BG}+1 / 2 \max \mathrm{SMF}$ & 0.882 & 5.913 & 33.511 & $\mathrm{BG}+1 / 2$ max PE 1 & 0.765 & 5.660 & 17.697 \\
\hline $\mathrm{C}$ & 0.907 & 6.905 & 46.781 & C & 0.849 & 6.526 & 47.159 \\
\hline$C+1 / 2 \max P 2$ & 0.770 & 5.363 & 31.955 & $\mathrm{C}+1 / 2 \max \mathrm{SNF}$ & 0.644 & 4.716 & 14.542 \\
\hline $\mathrm{C}+1 / 2 \max \mathrm{SMF}$ & 0.578 & 4.511 & 27.013 & $C+1 / 2 \max$ PE1 & 0.606 & 3.880 & 10.974 \\
\hline CG & 1.335 & 7.049 & 46.999 & CG & 1.256 & 6.838 & 48.463 \\
\hline $\mathrm{CG}+1 / 2 \max \mathrm{P} 2$ & 1.493 & 7.253 & 40.282 & $\mathrm{CG}+1 / 2 \max \mathrm{SNF}$ & 1.150 & 6.224 & 17.704 \\
\hline $\mathrm{CG}+1 / 2 \max \mathrm{SMF}$ & 1.105 & 5.631 & 32.095 & $C G+1 / 2 \max$ PE1 & 0.945 & 5.244 & 10.189 \\
\hline
\end{tabular}

Table 9. Analysis of Variance (ANOVA). One-dimensional significance tests for rheological parameters of mortar with P.

\begin{tabular}{|c|c|c|c|c|c|c|c|c|}
\hline \multirow{2}{*}{$\begin{array}{c}\text { Impact of CFA and P } \\
\text { on Rheological } \\
\text { Parameters of } \\
\text { Mortars }\end{array}$} & \multicolumn{2}{|c|}{$\mathrm{g} 5[\mathrm{Nmm}]$} & \multicolumn{2}{|c|}{$\mathrm{g} 90[\mathrm{Nmm}]$} & \multicolumn{2}{|c|}{ h5 $[\mathrm{Nmms}]$} & \multicolumn{2}{|c|}{$\mathrm{h} 90[\mathrm{Nmms}]$} \\
\hline & $\begin{array}{l}\text { The } \\
\text { Value of } \\
\text { F }\end{array}$ & $\begin{array}{c}\text { Level of } \\
\text { Significance } p\end{array}$ & $\begin{array}{l}\text { The } \\
\text { value of } \\
\text { F }\end{array}$ & $\begin{array}{c}\text { Level of } \\
\text { Significance } p\end{array}$ & $\begin{array}{l}\text { The } \\
\text { Value of } \\
\text { F }\end{array}$ & $\begin{array}{c}\text { Level of } \\
\text { Significance } p\end{array}$ & $\begin{array}{l}\text { The } \\
\text { Value of } \\
\text { F }\end{array}$ & $\begin{array}{c}\text { Level of } \\
\text { Significance } p\end{array}$ \\
\hline Type of $\mathrm{P}$ & 1.25945 & 0.120692 & 19.5596 & 1.85693 & 1.89624 & 0.190867 & 1.69624 & 0.255697 \\
\hline Dosage of $\mathrm{P}$, [\% b.m.] & 1. 95367 & 0.100815 & 13.5963 & 2.26472 & 1.69185 & 0.300257 & 1.23665 & 0.30236 \\
\hline $\begin{array}{c}\text { Raw and ground CFA; } \\
\text { batches and Dosage of } \\
\text { P, [\% b.m.] }\end{array}$ & 1.89637 & 0.140802 & 20.0119 & 1.01307 & 2.19993 & 0.093236 & 1.89624 & 0.140827 \\
\hline $\begin{array}{c}\text { Type of P and Dosage } \\
\text { of } \mathrm{P},[\% \mathrm{~b} . \mathrm{m} .]\end{array}$ & 2.71871 & 0.111022 & 12.5952 & 3.37841 & 1.19355 & 0.336703 & 1.10185 & 0.363647 \\
\hline
\end{tabular}

Significant statistical influence is marked in bold italics.

Table 10. ANOVA. One-dimensional significance tests for rheological parameters of mortar with SP.

\begin{tabular}{|c|c|c|c|c|c|c|c|c|}
\hline \multirow{2}{*}{$\begin{array}{c}\text { Impact of CFA and } \\
\text { SP on Rheological } \\
\text { Parameters of } \\
\text { Mortars }\end{array}$} & \multicolumn{2}{|c|}{ g5 [Nmm] } & \multicolumn{2}{|c|}{$\mathrm{g} 90[\mathrm{Nmm}]$} & \multicolumn{2}{|c|}{ h5 [Nmms] } & \multicolumn{2}{|c|}{$\mathrm{h} 90[\mathrm{Nmms}]$} \\
\hline & $\begin{array}{c}\text { The } \\
\text { Value of } \\
\text { F }\end{array}$ & $\begin{array}{c}\text { Level of } \\
\text { Significance } p\end{array}$ & $\begin{array}{c}\text { The } \\
\text { Value of } \\
F\end{array}$ & $\begin{array}{c}\text { Level of } \\
\text { Significance } p\end{array}$ & $\begin{array}{l}\text { The } \\
\text { Value of } \\
\text { F }\end{array}$ & $\begin{array}{c}\text { Level of } \\
\text { Significance } p\end{array}$ & $\begin{array}{c}\text { The } \\
\text { Value of } \\
\text { F }\end{array}$ & $\begin{array}{c}\text { Level of } \\
\text { Significance } p\end{array}$ \\
\hline Type of SP & 25.263 & 5.3485 & 5.7630 & 0.006398 & 2.536958 & 0.096357 & 2.5693 & 0.019653 \\
\hline Dosage of SP, [\% b.m.] & 1854.023 & 0.000000 & 512.1678 & 0.000000 & 52.2563 & 0.000569 & 23.45659 & 0.000215 \\
\hline $\begin{array}{c}\text { Raw and ground CFA; } \\
\text { batches and Dosage of } \\
\text { SP, [\% b.m.] }\end{array}$ & 54.996 & 13.8065 & 1.7850 & 0.015218 & 1.021517 & 0.498316 & 2.09643 & 0.081593 \\
\hline $\begin{array}{c}\text { Type of SP and } \\
\text { Dosage of SP, [\% b.m.] }\end{array}$ & 10.816 & 25.5603 & 1.3870 & 0.025324 & 1.315541 & 0.304389 & 2.76971 & 0.016045 \\
\hline
\end{tabular}

Significant statistical influence is marked in bold italics.

In the presence of P1 and especially P2, the negative influence of raw CFA on the yield value $g$ of mortars is clearly lower. After the addition of $0.5 \% \mathrm{P} 1$ or $\mathrm{P} 2$, the yield value g of the mortars with ground CFA is usually lower than that of mortar without CFA. For P1, this effect disappears over time, while for P2, it remains strong after $90 \mathrm{~min}$. P1 has an insignificant effect on the plastic viscosity h of 
the CFA mortar. P2 significantly reduces plastic viscosity $\mathrm{h}$. The addition of plasticizers makes the changes in the plastic viscosity h of the CFA mortars less significant over time. The results obtained are consistent with the results of the tests on cements containing CFA in $[16,17]$.

However, the increased SMF addition yield value $g$ of the CFA mortars generally remains higher than that of the mortar without CFA until the maximum recommended dose of SMF is applied (only for mortars with ground CFA). The presence of SMF accelerates the increase in yield value $g$ for mortars over time. This increase is greater for mortars containing CFA. In general, the impact of SMF on the plastic viscosity $\mathrm{h}$ of the tested mortars is insignificant from a workability point of view.

The test results agree with those in [24,41,42], in which it appears that admixtures based on melamine sulfonates demonstrate a possible decrease in the water content in concrete by up to $20 \%-30 \%$ compared to synthetic polymers, such as polycarboxylates and acrylic copolymers (PCEs), which have versatile chemical structures and can achieve up to $40 \%$ water reduction.

Obtaining consist CFA mortars to measure their rheological properties requires the addition of $1.8 \%$ SNF. When raw CFA is used, the yield values of these mortars range from 2.5 to 3.5 times higher than the yield values $g$ of the reference mortars, but when ground CFA is used, the yield value $g$ of mortars only ranges from 1.5 to 2 times higher. Increasing the amount of SNF to 3.6\% causes the yield value $g$ of the mortars with ground CFA to drop lower than that in the reference mortar (an average of $15 \%$ ). Mortars with raw CFA are then characterized by an average yield value g higher than $75 \%$. At a dose of up to $2.4 \%$, the SNF range of changes over time for the yield value $g$ of mortars with CFA is clearly higher than that of the reference mortar. When 3.6\% SNF is used, the increase in the yield value g over time for the reference mortar and mortars with ground CFA is negligible. To a small extent, the amount of SNF in the mortars with and without CFA influences the plastic viscosity $h$. The range of changes in the plastic viscosity h over time for the mortar and mortars with ground CFA is low and shows no clear trend; the workability these changes can thus be considered negligible. For mortars with raw CFA, with $2.4 \% \mathrm{SNF}$, they show a large decline in their plastic viscosity $\mathrm{h}$ resulting from stiffening of the mixture [26].

Obtaining consistent CFA mortars to measure the rheological properties requires the addition of $1 \%$ PE1 or $0.5 \%$ PE2. When raw CFA is used, the yield value of these mortars ranges from 2.2 to 3.4 times higher than the yield value $\mathrm{g}$ of the reference mortars, but when the ground CFA is used, the yield value $g$ of the mortars only ranges from 1.25 to 2 times higher. The increase in the yield value $g$ over time for the raw CFA mortars is very high, and after $90 \mathrm{~min}$, these mortars are too stiff to perform rheological measurements. The increase in the yield value $g$ of ground CFA mortars is usually clearly higher than that of the reference mortar (from 1.5 up to 2 times), but in some cases, it can be similar (PE1 or AG). The plastic viscosity h of the mortars with both ground and raw CFA is similar to or slightly higher than that of the reference mortar, and the plastic viscosity $h$ of the PE1 mortars is higher than that of the PE2 mortars. The plastic viscosity h of the P1 mortars generally does not change in 90 min, while that of the PE2 mortars decreases.

Further increasing the amount of PE1 and PE2 reduces the yield value $g$ and plastic viscosity $h$. This reduction is higher for mortars containing CFA. With the addition of $2 \%$ PE1 and $1 \%$ PE2, the rheological properties of the reference mortar and the mortars with ground CFA are similar (sometimes the yield value $g$ of ground CFA is even lower), and the mortars do not show significant changes in their yield value over time. For the raw CFA mortars, the yield value $g$ and its growth over time are reduced by increasing the SP addition but remain considerably higher than those of the reference mortar. Increasing the dose of PE1 insignificantly influences the plastic viscosity $\mathrm{h}$ of the mortars. This is due to the properties of raw CFA and the high water demands, which were confirmed in [16,22]. Increasing the dose of PE2 lowers the plastic viscosity $h$ of the mortars with ground CFA and increases the plastic viscosity $h$ of the mortars with raw CFA. The plastic viscosity $h$ of the mortars with raw CFA with PE2 at a dose of $0.75 \%$ significantly decreases, and with a dose of 1.0\% PE2, it insignificantly increases.

The effects of $\mathrm{P}$ and SP action are affected by the type of CFA. On the basis of the conducted studies, it is not possible to identify clear trends. However, the use of $\mathrm{P}$ and SP reduces the influence 
of the type of CFA (particularly when the CFA is ground ) on the rheological properties of mortars (particularly when large amounts of $\mathrm{P}$ and SP), but the influence of CFA type may still be noticeable even if the maximum recommended dose is used.

The introduction of P1, SMF, and PE1 does not aerate the mortars, while the use of P2, SNF, and PE2 does aerate the mortars, both with and without CFA, as shown in Table 7. This effect may be partially responsible for the relatively smaller plastic viscosity of the mortars with the addition of P2, SNF, and PE2.

The introduction of P2, SMF, SNF, and PE1 reduces the cement hydration heat emitted after $2 \mathrm{~h}$ by $60-80 \%$, as shown in Table 8. These results are consistent with those of other studies in this field [43]. In the presence of CFA, the reduction in the amount of heat released by adding these admixtures is smaller and ranges from $10 \%$ to $45 \%$, depending on the nature and processing of the CFA (without showing clear trends). This indicates the retarding effect of admixtures, which is lower in the presence of CFA. The reasons for this can also be seen in the mechanism of the increased absorption of $\mathrm{P}$ and SP described above by large, irregular CFA grains. This phenomenon causes a smaller amount of $\mathrm{P}$ and $\mathrm{SP}$ to act in the cement paste, thereby exerting a smaller effect on the hydration process. It should be noted that a reduction in the heat generated after $2 \mathrm{~h}$ and $12 \mathrm{~h}$ by PE1 is higher than that for SMF and SNF. This indicates the strong retarding effect of PE1.

\section{Evaluation of the Effectiveness of Plasticizers and Superplasticizers in the Presence of CFA}

Evaluation of the effectiveness of $\mathrm{P}$ and SP in the presence of CFA was focused on the changes in the yield value $g$ of mortars. Thus, the initial yield value $g$ and its changes over time were taken into account. Plastic viscosity $\mathrm{h}$, as indicated earlier, is normally of secondary importance to the mixture's workability. Additionally, as shown in this research, the range of plastic viscosity h changes in mortars due to the addition of $\mathrm{P}$ or SP with or without CFA is, in most cases, insignificant.

The obtained results for PL and SP activity do not indicate that the presence of CFA significantly affects their mechanisms of action described in $[24,44]$. The introduction of CFA as a cement replacement, due to its increased water demands, reduces the amount of free water in the mixture. Accordingly, mortars with CFA are characterized by a much higher yield value $g$ and a faster increase in the yield value $g$ over time than in mortar without CFA. Thus, to obtain a certain yield value $g$ of mortars with CFA, it is necessary to use a higher addition of $\mathrm{P}$ or SP than for similar mortars without CFA. The amounts of P1 and P2 and SNF, SMF, and PE necessary to obtain a mortar yield g equal to $20 \mathrm{Nm}$ are shown in Figures 14a and 15a. These relationships demonstrate the beneficial effect of using ground CFA. Obtaining the specific yield value $g$ of ground CFA mortars requires a significantly lesser amount of admixture than that of raw CFA mortars. Importantly, it also shows that immediately after mixing, in the presence of ground CFA, plasticizers P1 and P2 are more effective, while the superplasticizers SNF, PE1, and PE2 and SMF are significantly less effective than in mortars without CFA. Only the effectiveness of P1 and SMF depend on the type of CFA; the effectiveness of the other types of admixtures, to a lesser extent, depends on the type of CFA, especially when the CFA is ground. The increase in the yield value $g$ of mortars with an initial yield of $20 \mathrm{Nm}$ is shown in Figures 14b and $15 \mathrm{~b}$. This increase is generally much higher for mortars with CFA, especially when raw CFA and SMF and PE2 are used. Only for P2 and PE1 is the increase in the yield value g over time for mortars with ground CFA less than or similar to that for mortars without CFA. This means that the effectiveness of $\mathrm{P}$ and SP with respect to time of action is generally reduced in the presence CFA. Analyzing the available literature $[1,24,42,44,45]$ shows that the morphology of CFA grains affects the lower efficiency of $\mathrm{P}$ and SP. Raw CFA is characterized by large, porous grains with a large developed surface, which also contain large porous residues of unburned coal. This is the reason for the increased absorption of $\mathrm{P}$ and SP on CFA grains. This phenomenon significantly reduces the amount of admixtures that can work effectively in a cement mix. During processing by grinding, large grains are destroyed, which both reduces the CFA's water demand [14] and contributes to an increase in the amount of active P 
or SP. The CFA processed by grinding increases the effects of the admixtures in comparison with the operations in cement mixes modified by raw CFA.

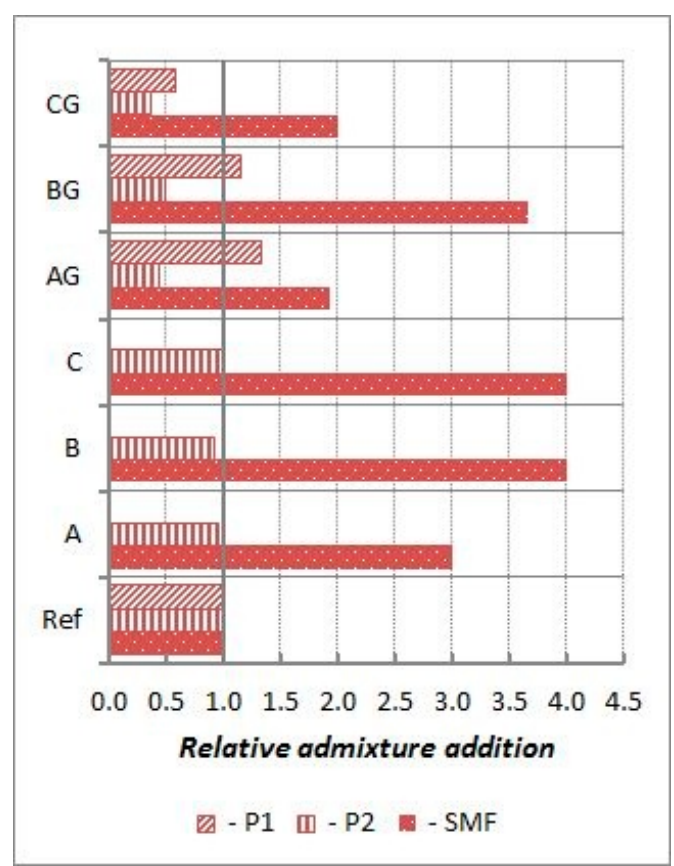

(a)

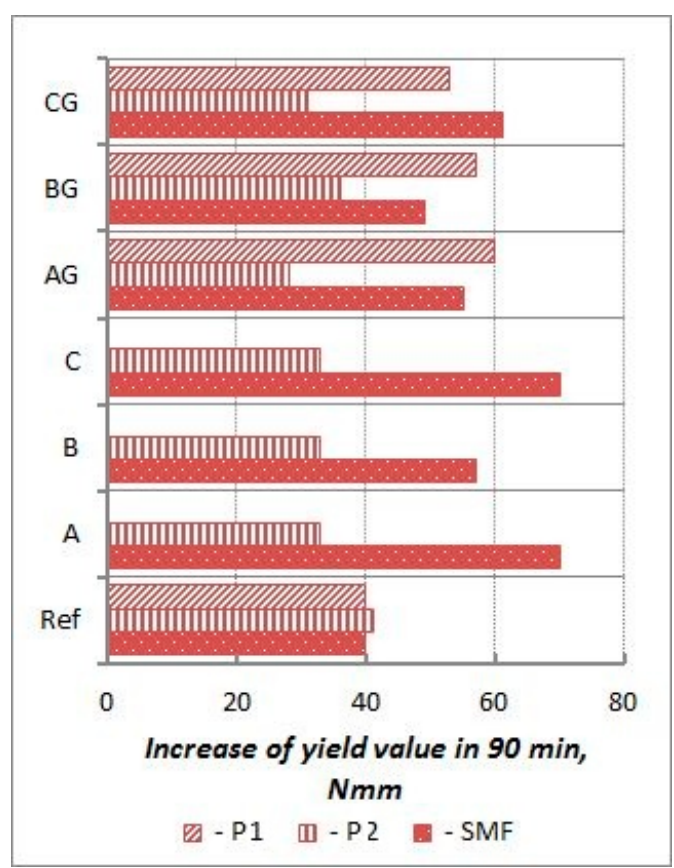

(b)

Figure 14. Influence of CFA on effectivness of P1, P2 and SMF (mortars of $w / b=0.55$ ); (a) relative admixture content (in relation to reference mortar without CFA) neccessary to be added to obtain mortar with g5 = $20 \mathrm{Nmm}$; (b) increase in yield value $g$ of mortars with initial yield value g equal $20 \mathrm{Nmm}$ in time.

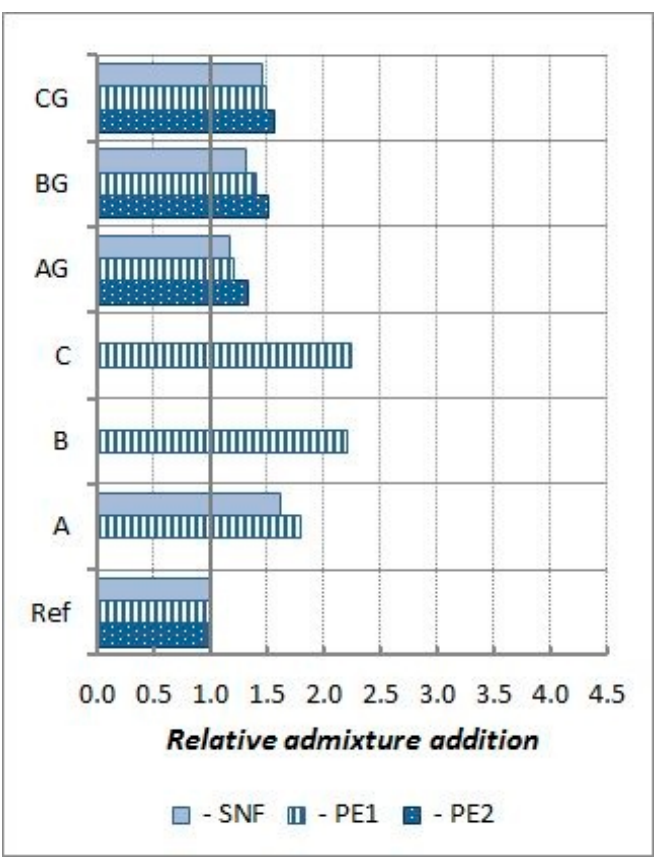

(a)

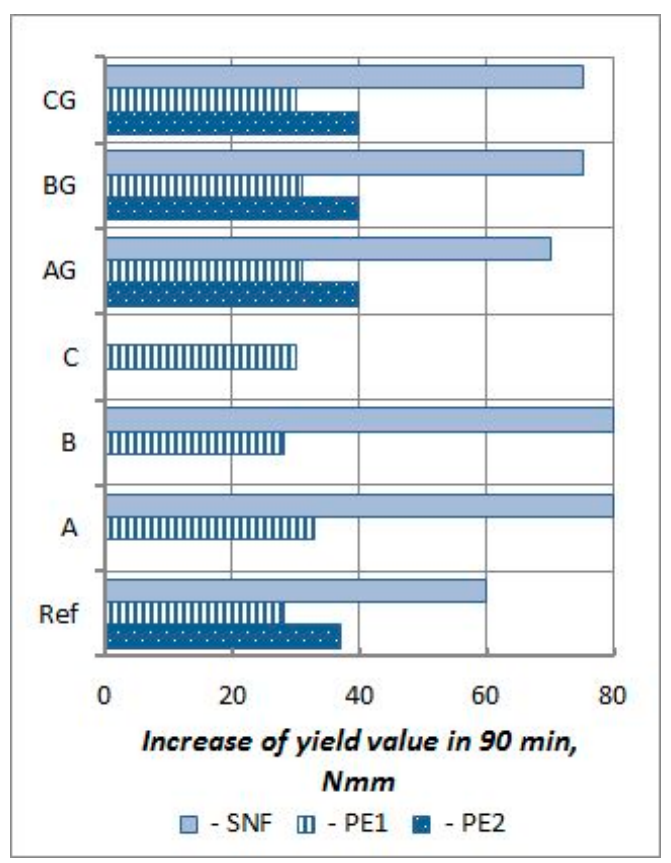

(b)

Figure 15. Influence of CFA on effectivness of SNF, PE1 and PE2 (mortars of $w / b=0.45$ ); (a) relative admixture content (in relation to reference mortar without CFA) neccessary to be added to obtain mortar with g5 = $20 \mathrm{Nmm}$; (b) increase in yield value $\mathrm{g}$ of mortars with initial yield value $\mathrm{g}$ equal $20 \mathrm{Nmm}$ in time. 
For mortars with CFA, the effectiveness of $\mathrm{P}$ and SP in the presence of CFA was also analyzed according to the changes in the initial yield value $\mathrm{g} 5$ and the increase in the yield value $\mathrm{g}$ over time of up to $90 \mathrm{~min}$ (g90-g5) caused by the addition of these admixtures compared to the analogous changes of (i) the reference mortar (without CFA) and (ii) the CFA mortar without an admixture. The relative influence of CFA type and processing on the effectiveness of P and SP is shown in Figures 16 and 17.

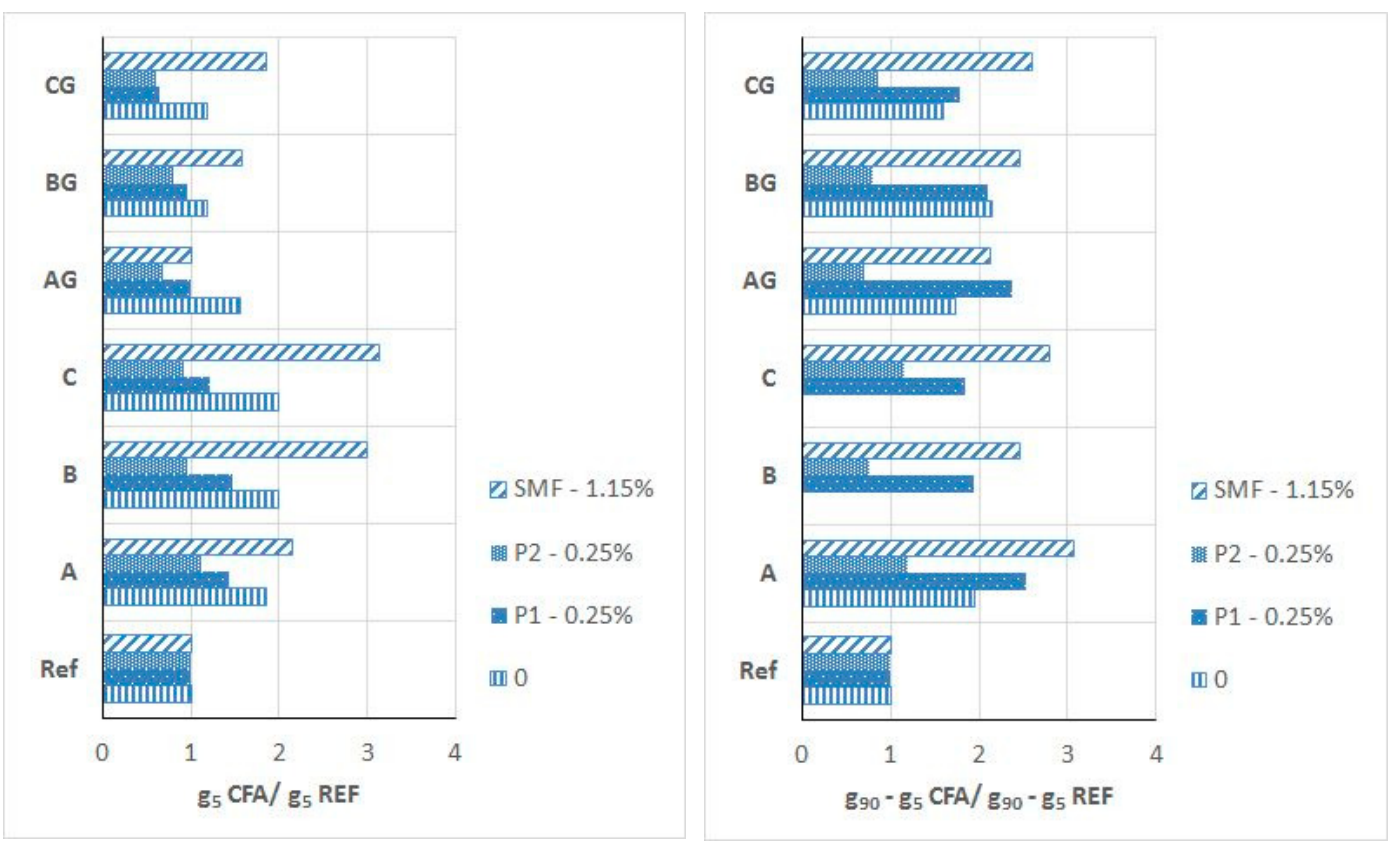

Figure 16. Relative effect of CFA presence on initial yield value g (g5) and yield value g increase in time (g90-g5) of mortars in respect to reference mortars REF without CFA (Mortars without and with $\mathrm{P} 1$ or $\mathrm{P} 2$ or SMF $-1 / 2$ of recommended maximum dosage, $\mathrm{w} / \mathrm{b}=0.55)$.
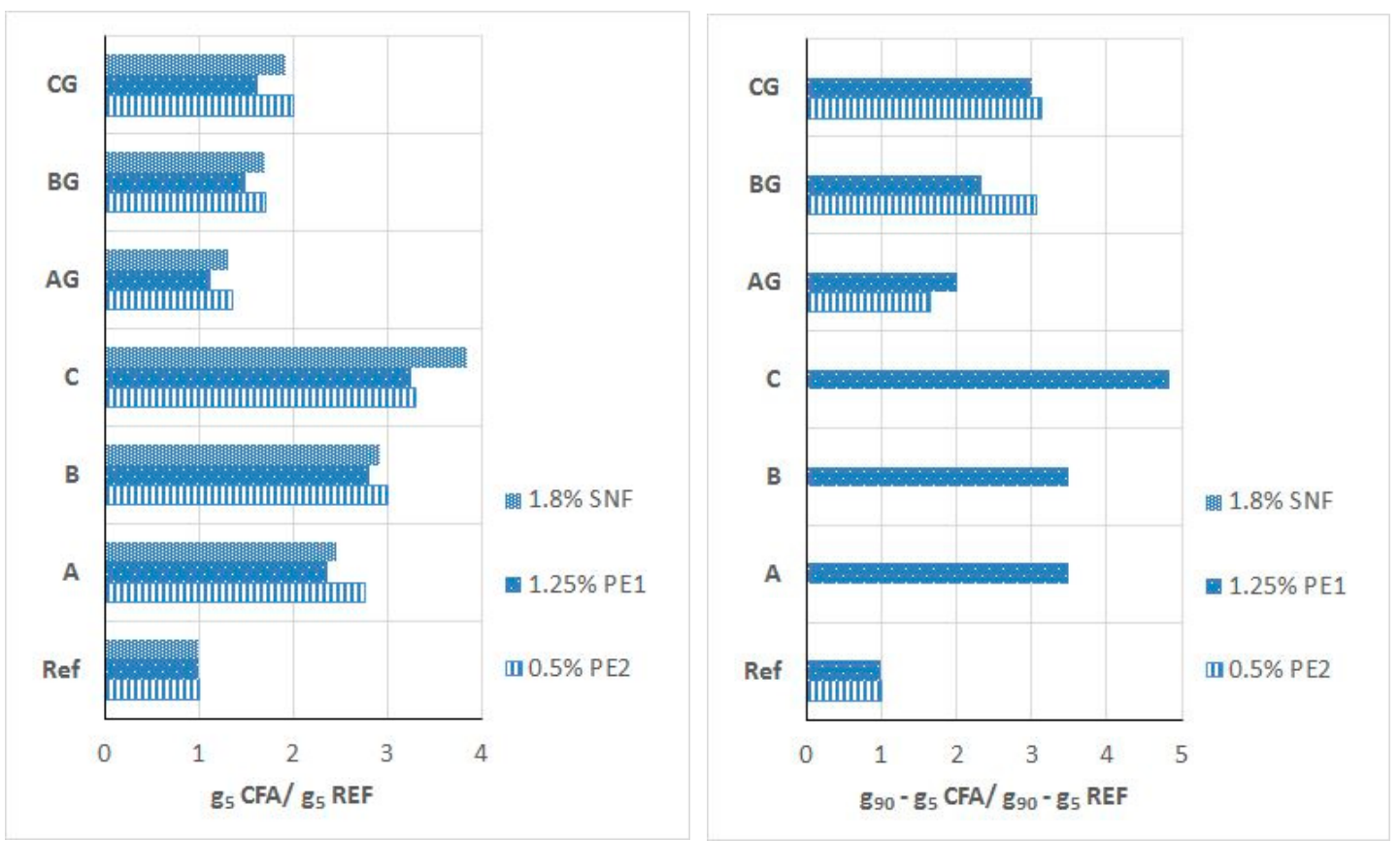

Figure 17. Relative effect of CFA presence on initial yield value $g(g 5)$ and yield value $g$ increase in time (g90-g5) of mortars in respect of reference mortars without CFA. (Mortars with SNF or PE1 or PE2 $-1 / 2$ of recommended maximum dosage, $\mathrm{w} / \mathrm{b}=0.45$ ). 
The presence CFA favourably impacts the initial effectiveness of P1 and P2. The range of the reduction of the yield value $g$ caused by the addition of $P$ is higher in the mortars with CFA, particularly in mortars with ground CFA. The yield value $g$ of the ground CFA mortars with a P addition of $0.25 \%$ is always lower than that of the mortars without CFA. The presence of CFA negatively affects the effectiveness of P1 with respect to workability changes over time. The relative increase in the yield value g over time for all mortars with CFA and P1, but especially those with raw CFA, is significantly higher than that for analogical mortar without CFA. At the same time, the presence of CFA favourably impacts the effectiveness of P2. The relative increase in the yield value g over time for mortars with P2 and with unprocessed and (particularly) ground CFA is lower than that of the mortar without CFA. Thus, using processing with CFA increases the effectiveness of $P$.

The effectiveness of SMF in the presence of CFA is clearly lower. The relative reduction of the initial yield value $g$ of the CFA mortars is lower than of the mortar without CFA, even when the ground CFA is used. It should be noted, however, that despite lower effectiveness in the presence of CFA, the effects of SMF action remain higher than those of P1 and P2. The effects that adding SMF have quickly disappear over time (faster than for P1 and P2), which is typical for this type of admixture [24]. With the addition of $1.15 \%$, the SMF increase in the yield value $g$ of the mortars with ground CFA is clearly higher than that in the reference mortar and even higher than that in mortars without the addition of SMF. This means that the effectiveness of SMF with respect to time is vulnerable to CFA, especially raw CFA.

The initial effectiveness of the SNF in the presence of ground CFA does not reduce significantly but, at the same time, is reduced in the presence of raw CFA. Thus, at an SNF dose close to maximum, the mortar with ground CFA has a lower yield value $g$ than the mortar without CFA. For workability loss, the effectiveness of SNF in the presence of CFA (both raw and ground) is reduced. Only at a dose of 3.6\% SNF (the maximum recommended dose) was it possible to obtain ground CFA mortars with the range of changes in yield value g over time analogous to those of the mortar without CFA. In conclusion, the presence of CFA reduces the effectiveness of SNF. This reduction is lower when ground CFA is used.

The initial effectiveness of PE1 in the presence of ground CFA is higher but decreased in the presence of raw CFA. At $2 \%$ and higher dosages of PE1, the mortars with ground CFA achieve a similar yield to the mortars without CFA. In terms of workability loss, the effectiveness of PE1 in the presence CFA is lower. However, it should be noted that at high PE1 dosages, the workability loss of the ground CFA mortars and the reference mortar is negligible. On the other hand, the mortars with raw CFA show a considerable loss of workability even when the maximum recommended dose of PE1 is used. Thus, the presence of raw CFA reduces the effectiveness of PE1, but the presence of ground CFA affects it much less significantly.

The effectiveness of PE2 is generally lower than that of PE1. The presence of CFA, especially raw CFA, reduces the effectiveness of PE2. At a dose of $0.50 \%$, PE2 was able to fluidize the raw CFA mortar only to a small extent. The mortars with raw and ground CFA present a rapid workability loss-much faster than that of the reference mortar. Increasing the dose of PE2 slightly reduces the yield value $g$ of mortars with raw CFA, but even at its maximum recommended dose, such mortars show a rapid workability loss. An increased dose of PE2 strongly influences the reduction of the yield value $g$ of mortars with ground CFA. At the maximum dosage, the yield values of these mortars are smaller than those of the reference mortar. The mortar with ground CFA still shows a rapid loss of workability. Therefore, in general, the presence of CFA negatively impacts the effectiveness of PE2, but to a lesser degree when ground CFA is used.

The type of CFA affects the efficiency of all tested SP. However, based on the current research, it is not possible to identify clear trends (SP usually works clearly better in the presence of CFA-type A and worse with CFA type $C$, but this effect cannot be clearly linked to the specific properties of the CFA). With an increased amount of SP, the influence of the type of CFA on the rheological parameters of the 
mortar is reduced. However, for raw CFA, even at the maximum recommended dosage, this influence remains evident.

\section{Conclusions}

We confirmed that the use of raw CFA has a very negative impact on the workability of mortars. This effect is much less if ground CFA is used. The practical application of this ash without the simultaneous use of plasticizers or superplasticizers can be difficult in many cases.

The use of an admixture, particularly SP, allows one to effectively control the workability of mortar containing CFA, especially ground CFA. With these admixtures, it is possible to obtain mortars containing ground CFA with similar rheological properties to mortars without this addition. To obtain a specific workability of mortar with CFA, it is usually necessary to introduce a higher dose of a P or SP than found in mortar without CFA.

The presence of CFA also influences the effectiveness of the P and SP. This effect depends mostly on the rheological admixture type and CFA processing. Table 11 presents the general results of the impact of raw and ground CFA additions on the technical effectiveness of $\mathrm{P}$ and SP. With a value of $(-1)$ for obtaining the specified effect of mix workability, a higher admixture dosage is necessary, and with a value of $(-2)$, a higher admixture dosage is necessary (or the specified mix's workability may be impossible).

Table 11. Influence of raw and ground CFA addition on the technical effectiveness level of $P$ and SP action.

\begin{tabular}{ccc}
\hline Type of Admixture & In Raw CFA Presence & In Ground CFA Presence \\
\hline P: & Technical effectiveness of P action \\
\hline $\begin{array}{c}\text { P1- lignosulfonates }(\max 0.5 \%) \\
\text { P2- iminodietanol, bis ethanol, } \\
\text { phosphate }(V) \text { tri butyl acetate, } \\
\text { formaldehyde, methanol, }\end{array}$ & $2 *$ & $2 *$ \\
$\begin{array}{c}\text { (Z)-octadec-9-enyloamine }(\max 0.5 \%) \\
\text { SP: }\end{array}$ & Technical effectiveness of SP action \\
\hline \begin{tabular}{c} 
SMF- melamine sulfonates $(\max 2.3 \%)$ \\
\hline SNF- naphthalene sulfonate $(\max 3.6 \%)$
\end{tabular} & $-2 *$ & $-2 *$ \\
\hline PE1- polycarboxylate ether $(\max 2.5 \%)$ & $-2 *$ & $0 *$ \\
\hline PE2- polycarboxylate ether $(\max 1.0 \%)$ & $-2 *$ & $-1 *$ \\
\hline
\end{tabular}

Explanation of symbols in the table: ${ }^{*}-2$ - significantly reduced efficiency compared to operation without CFA; -1 slightly reduced efficiency compared to operation without CFA; 0- unchanged efficiency compared to operation without CFA; 1- slightly increased efficiency compared to operation without CFA; 2- significantly increased efficiency compared to operation without CFA.

The properties of CFA have an impact on the effectiveness of P and SP; this effectiveness is clearly lower when ground CFA is used. In the presence of CFA, the secondary effects of using P or SP for air entrainment or setting the time are similar. However, the effects of these admixtures on the heat of hydration are lower in the presence of CFA.

The obtained results may be used as an indicator for admixture selection or for the workability design of fresh mortars and concretes containing CFA. The use of P or SP allow one to effectively use CFA in concrete technology as a concrete or cement additive and thereby obtain significant environmental benefits. However, the selection of specific P or SP should always be verified experimentally while taking into account the CFA and cement's properties, as well as the specific demands of the mixture's workability and the secondary effects of the admixture. 
Author Contributions: The authors declare equal participation in the research and preparation of manuscript. All authors have read and agreed to the published version of the manuscript. Conceptualization, J.G. and T.P.; methodology, T.P. and A.K.-S.; software, J.G., T.P. and A.K.-S.; validation, J.G., T.P. and A.K.-S.; formal analysis, J.G.; investigation, A.K.-S. and P.M.; resources, A.K.-S. and P.M.; data curation, A.K.-S. and P.M.; writing-original draft preparation, J.G.; writing-review and editing, T.P. and A.K-S.; visualization, A.K-S.; supervision, J.G.; project administration, J.G.; funding acquisition, T.P. and J.G.

Funding: This research was funded by the European Union from the European Regional Development Fund. No. POIG 01.01.02-24-005/09, Innovative cement based materials and concrete with high calcium fly ashes.

Conflicts of Interest: The authors declare no conflict of interest.

\section{References}

1. Giergiczny, Z. Fly ash and slag. Cem. Concr. Res. 2019, 124,1-18. [CrossRef]

2. Baran, T.; Drozdz, W. Evaluation of properties of domestic calcareous fly ash and its processing methods. Roads Bridges Drog. Mosty 2013, 12, 5-15.

3. EN 197-1. Cement-Part 1: Composition, Specifications and Conformity Criteria for Common Cements; British Standards Institution (BSI): London, UK, 2011.

4. Dziuk, D.; Giergiczny, Z.; Garbacik, A. Calcareous fly ash as a main constituent of common cements. Roads Bridges Drog. Mosty 2013, 12, 57-69.

5. Giergiczny, Z.; Garbacik, A.; Ostrowski, M. Pozzolanic and hydraulic activity of calcareous fly ash. Roads Bridges Drog. Mosty 2013, 12, 71-81.

6. Giergiczny, Z.; Synowiec, K.; Żak, A. Suitability evaluation of calcareous fly ash as an active mineral additive to concrete. Roads Bridges Drog. Mosty 2013, 12, 83-97.

7. Czopowski, E.; Łaźniewska-Piekarczyk, B.; Rubinska-Jonczy, B.; Szwabowski, J. Properties of concretes based on cements containing calcareous fly ash. Roads Bridges Drog. Mosty 2013, 12, 31-40.

8. Dabrowska, M.; Giergiczny, Z. Chemical resistance of mortars made of cements with calcareous fly ash. Roads Bridges Drog. Mosty 2013, 12, 131-146.

9. Drożdż, W.; Giergiczny, Z. The resistance of mortars and concrete with calcareous fly ash on alkaline corrosion. Roads Bridges Drog. Mosty 2013, 12, 147-158.

10. Jóźwiak-Niedźwiedzka, D.; Sobczak, M.; Gibas, K. Carbonation of concretes containing calcareous fly ashes. Roads Bridges Drog. Mosty 2013, 12, 223-236.

11. Gibas, K.; Glinicki, M.A.; Nowowiejski, G. Evaluation of impermeability of concrete containing calcareous fly ash in respect to environmental media. Roads Bridges Drog. Mosty 2013, 12, 157-172.

12. Gołaszewski, J.; Kostrzanowska, A.; Ponikiewski, T.; Antonowicz, G. Influence of calcareous fly ash on rheological properties of cement pastes and mortars. Roads Bridges Drog. Mosty 2013, 12, 99-112.

13. Panda, B.; Ruan, S.; Unluer, C.; Tan, M.J. Improving the 3D printability of high volume fly ash mixtures via the use of nano attapulgite clay. Compos. Part B Eng. 2019, 165, 75-83. [CrossRef]

14. Gołaszewski, J.; Giergiczny, Z.; Ponikiewski, T.; Kostrzanowska-Siedlarz, A.; Miera, P. Effect of calcareous fly-ash processing methods on rheological properties of mortars. Period. Polytech. Civil Eng. 2018, 62, 643-652. [CrossRef]

15. Giergiczny, Z. Rola Popiołów Lotnych Wapniowych i Krzemionkowych w Kształtowaniu Właściwości Wspótczesnych Spoiw Budowlanych i Tworzyw Cementowych (The Role of Calcereous and Silicous Fly Ash in the Shaping of Modern Construction and Cement Binders Properties); Monografia, Politechnika Krakowska: Kraków, Poland, 2006. (In Polish)

16. Gołaszewski, J.; Kostrzanowska- Siedlarz, A.; Ponikiewski, T.; Miera, P. Influence of Cements Containing Calcareous Fly Ash as a Main Component Properties of Fresh Cement Mixtures. IOP Conf. Ser. Mater. Sci. Eng. 2017, 245, 022099. [CrossRef]

17. Gołaszewski, J.; Kostrzanowska- Siedlarz, A.; Ponikiewski, T.; Miera, P. Influence of Multicomponent and Pozzolanic Cements Containing Calcareous Fly Ash and Other Mineral Admixtures on Properties of Fresh Cement Mixtures. IOP Conf. Ser. Mater. Sci. Eng. 2019, 471, 112024. [CrossRef]

18. Nowoświat, A.; Gołaszewski, J. Influence of the Variability of Calcareous Fly Ash Properties on Rheological Properties of Fresh Mortar with Its Addition. Materials 2019, 12, 1942. [CrossRef]

19. Wei, S.; Handong, Y.; Binggen, Z. Analysis of mechanism on water-reducing effect of fine ground slag, high-calcium fly ash, and low-calcium fly ash. Cem. Concr. Res. 2003, 33, 1119-1125. [CrossRef] 
20. Yazıc1, H. The effect of silica fume and high-volume Class $\mathrm{C}$ fly ash on mechanical properties, chloride penetration and freeze-thaw resistance of self-compacting concrete. Constr. Build. Mater. 2008, 22, 456-462. [CrossRef]

21. Felekoğlu, B.; Türkel, S.; Kalyoncu, H. Optimization of fineness to maximize the strength activity of high calcium ground fly ash-Portland cement composites. Constr. Build. Mater. 2009, 23, 2053-2061. [CrossRef]

22. Gołaszewski, J.; Ponikiewski, T.; Kostrzanowska, A. The influence of High Calcium Fly Ash on rheological properties of cement mixtures. In Non-Traditional Cement $\mathcal{E}$ Concrete IV, Proceedings of the International Conference, Brno, Czech Republic, 27-30 June 2011; Bilek, V., Keršner, Z., Eds.; University of Technology: Brno, Czech Republic, 2011; pp. 410-419.

23. Ponikiewski, T.; Gołaszewski, J. The influence of high-calcium fly ash on the properties of fresh and hardened self-compacting concrete and high performance self-compacting concrete. J. Clean. Prod. 2014, 72, 212-221. [CrossRef]

24. Ramachandran, V.S. Concrete Admixtures Handbook. Properties, Science and Technology, 2nd ed.; Noyes Publications: Park Ridge, NJ, USA, 1995; ISBN 0-8155-1373-9.

25. Gołaszewski, J. Correlation between Rheology of Superplasticized Fresh Mortars and Fresh Concretes. In Superplasticizers and other Admixtures in Concrete, Proceedings of the 9th ACI International Conference Superplasticizers and Other Chemical Admixtures, Seville, Spain, 13-17 October 2009; Malhotra, V.M., Ed.; American Concrete Institute (ACI): Farmington Hills, MI, USA, 2009; pp. 215-236, SP-262-16.

26. Gołaszewski, J. The influence of cement paste volume in mortar on the rheological effects of the addition of superplasticizer. In Brittle Matrix Composites 8; Brandt, A.M., Li, V.C., Marshall, I.H., Eds.; Woodhead Publishing: Cambridge, UK, 2007; pp. 441-450. ISBN 978-1-8456-9031-1.

27. Gołaszewski, J. Influence of cement properties on new generation superplasticizers performance. Constr. Build. Mater. 2012, 35, 586-596. [CrossRef]

28. Banfill, P.F.G. The rheology of fresh cement and concrete-A review. In Proceeding of the 11th International Cement Chemistry Congress, Durban, South Africa, 11-16 May 2003; pp. 50-63.

29. Banfill, P.F.G. The rheology of fresh mortar. Mag. Concr. Res. 1991, 43, 13-21. [CrossRef]

30. Norberg, J.; Peterson, O.; Billberg, P. Effects of a New Generation of Superplasticizers on the Properties of Fresh Concrete. In Superplasticizers and other Admixtures in Concrete, Proceedings of the 5th ACI International Conference Superplasticizers and Other Chemical Admixtures, Rome, Italy, 9 January 1997; Malhotra, V.M., Ed.; American Concrete Institute (ACI): Farmington Hills, MI, USA, 1997; pp. 583-598.

31. Helm, M.; Hornung, F. Rheological test procedure in the ready-mixed concrete bath plant. Annu. Trans. Nord. Rheol. Soc. 1997, 5, 106-108.

32. Petit, J.Y.; Khayat, K.H.; Wirquin, E. Yield stress and viscosity equations for mortars and self-consolidating concrete. Cem. Concr. Res. 2007, 37, 655-670. [CrossRef]

33. Gołaszewski, J.; Kostrzanowska-Siedlarz, A.; Cygan, G.; Drewniok, M. Mortar as a model to predict self-compacting concrete rheological properties as a function of time and temperature. Constr. Build. Mater. 2016, 124, 1100-1108. [CrossRef]

34. PN-EN 196-6:2011 Methods of testing cement. Determination of fineness.

35. ASTM C618 Standard Specification for Coal Fly Ash and Raw or Calcined Natural Pozzolan for Use in Concrete.

36. PN-EN 450-1:2012. Fly ash for concrete. Definition, specifications and conformity criteria.

37. PN-EN 196-1:2006. Methods of testing cement. Determination of strength.

38. Tattersall, G.H.; Banfill, P.F.G. The Rheology of Fresh Concrete; Pitman Advanced Publishing Program: Boston, MA, USA, 1983; ISBN 0-273-08558-1.

39. Roussel, N. Understanding the Rheology of Concrete; Woodhead Publishing: Cambridge, UK, 2011; p. 384.

40. PN-EN 1015-7:2000. Methods of test for mortar for masonry. Determination of air content of fresh mortar.

41. Gelardi, G.; Mantellato, S.; Marchon, D.; Palacios, M.; Eberhardt, A.B. Chemistry of chemical admixtures. In Science and Technology of Concrete Admixtures, 1st ed.; Aïcin, P.C., Flatt, R., Eds.; Woodhead Publishing: Cambridge, UK, 2016; pp. 149-218. ISBN 978-0-0810-0696-2.

42. Nkinamubanzi, P.C.; Mantellato, S.; Flatt, R.J. Superplasticizers in practice. In Science and Technology of Concrete Admixtures, 1st ed.; Aïtcin, P.C., Flatt, R., Eds.; Woodhead Publishing: Cambridge, UK, 2016; pp. 353-377. ISBN 978-0-0810-0696-2. 
43. Nocun-Wczelik, W.; Trybalska, B. Wpływ wybranych domieszek chemicznych na szybkość hydratacji i mikrostrukture zaczynu cementowego. Cem. Wapno Beton 2007, 6, 284-289.

44. Kurdowski, W. Cement and Concrete Chemistry; Springer: Berlin/Heidelberg, Germany, 2016; ISBN 9789402405941.

45. Urban, M. Wpływ wielkości strat prażenia popiołu lotnego krzemionkowego na parametry reologiczne mieszanek nowej generacji. Cem. Wapno Beton 2007, 4, 193-200. 